\title{
A correlation of breast cancer and calcium levels in hair analyzed by X-ray fluorescence
}

\author{
Jun-ichi Chikawa ${ }^{\mathrm{a}, *}$, Yoshitaka Mouri ${ }^{\mathrm{b}}$, Hiroki Shima ${ }^{\mathrm{c}}$, Kousaku Yamada ${ }^{\mathrm{a}}$, \\ Hitoshi Yamamoto ${ }^{\mathrm{d}}$ and Shingo Yamamoto ${ }^{\mathrm{e}}$ \\ ${ }^{a}$ Hyogo Science and Technology Association, Himeji, Japan \\ ${ }^{\mathrm{b}}$ Himeji Health Centre, Sakata, Himeji, Japan \\ 'Shima Institution for Quantum Medicine, Nakatsu, Kita-ku, Osaka, Japan \\ ${ }^{\mathrm{d}}$ Osaka Breast Clinic, Fukushima, Fukushima-ku, Osaka, Japan \\ ${ }^{\mathrm{e}}$ Hyogo College of Medicine, Mukogawa, Nishinomiya, Hyogo, Japan
}

Received 2 September 2013

Revised 7 April 2014

Accepted 4 June 2014

\begin{abstract}
Time variations of elemental concentrations and their abnormalities due to breast cancer have been observed along single hair strands by X-ray fluorescence excited by synchrotron radiation. The renal-controlled elements $\mathrm{Ca}, \mathrm{Sr}, \mathrm{S}, \mathrm{K}, \mathrm{Cl}, \mathrm{Br}$ and $\mathrm{P}$ have upper and lower levels associated with gating and closing of ion channels in the hair-making cells. The Ca lower level is normal. In cases of Ca deficiency, with a decrease from the normal, store-operated Ca channel gating occurs so as to keep the hair $\mathrm{Ca}$ at the normal, and paradoxically high $\mathrm{Ca}$ levels near or at the upper level are produced by PTH-operated channel gating of the cells. Chronic Ca deficiency shows a temporal pattern along the hair consisting of a long-term duration of the upper [Ca] level, 10-month long decay to the lower level and abrupt increase to the upper level. The observation for hair from breast-cancer patients also shows the upper $\mathrm{Ca}$ level for the time period well before detection, and suggests that cancer is always generated at the long-lasting [Ca] upper level and the hair [Ca] decreases gradually toward the lower level with the cancer growth. This decay of [Ca] is accompanied by those of [Sr] and [K]. Their different decay forms can be explained by parathyroid hormone related peptide (PTHrP) in serum secreted from the cancer having 150 times longer dwell time on the PTH receptors than that of PTH. Patient hair has a memory for the entire cancer process from the state before cancer generation, and the pattern can be distinguished from concentration variation due to the chronic Ca deficiency without cancer, leading to a criterion for cancer detection by the ratio of $[\mathrm{Sr}] /[\mathrm{Ca}]$. The hair analysis is useful for early detection of cancer.
\end{abstract}

Keywords: Hair and serum elements, Ca deficiency, ion channels, PTH, PTHrP, breast cancer, Sr/Ca ratio

\section{Introduction}

Cancer is known as a distinct type of genetic disease from the accumulation of several mutations [1]. As an initial or boundary condition for this genetic principle, relations between $\mathrm{Ca}$ metabolism and cancer incidence should be investigated, since $\mathrm{Ca}$ ion is a messenger in the universal cellular signal transduction. Epidemiological investigations have been carried out for effects of $\mathrm{Ca}$ intake on cancer with positive [2] and negative [3] results. Various studies on animal models with dietary Ca restriction

\footnotetext{
${ }^{*}$ Corresponding author: Jun-ichi Chikawa, Hyogo Science and Technology Association, Shimodera-cho 43, Himeji, 6708505, Japan. Tel.: +81 79287 1212; Fax: +81 79287 1220; E-mail: chikawa@hyogosta.jp.
}

0895-3996/14/\$27.50 (c) 2014 - IOS Press and the authors. All rights reserved

This article is published online with Open Access and distributed under the terms of the Creative Commons Attribution NonCommercial License. 
have shown an abnormal Ca metabolism termed "Ca paradox". These studies and epidemiological investigations have led to abnormal calcium being identified as an origin of various diseases [4]. Because calcium irregularities such as calcified cysts have been noted in breast-cancer patients, it seemed likely to expect calcium abnormalities in other tissue. To give decisive evidence for such hypotheses, we need a new method to detect disorders of $\mathrm{Ca}$ homeostasis over the long term cancer process.

It has been shown in the previous paper [5] that X-ray fluorescence analysis (XFA) along a single hair strand from a healthy subject reveals homeostasis that keeps the normal [Ca] level from root to tip over a long term more than 6 months (hair growth rate of $1 \mathrm{~cm} / \mathrm{month}$ ). However, hair from general subjects has two separate levels of concentration $[\mathrm{Ca}]_{\mathrm{H}}$; the upper level is 5 times higher than the lower normal level. Content of an element in hair growing in a steady state must be equal to its inflow into the hair matrix cells via hair papilla (hair-making cells, HM cells) from serum. By this principle of "the inflowoutflow equality", the upper level and lower level of hair $[\mathrm{Ca}]_{\mathrm{H}}$ correspond to gating and closing of $\mathrm{Ca}$ ion channels in the HM cells, respectively. The Ca channel gating is considered to be regulated by the parathyroid hormone (PTH) secreted with Ca deficiency [4,6]. Concentration variations from hair root to tip for breast-cancer patients suggest that cancer is generated during the long-lasting upper level of hair $[\mathrm{Ca}]_{\mathrm{H}}$ which decreases toward the lower level with the cancer growth [5]. In the previous work [5], this decay of $[\mathrm{Ca}]_{\mathrm{H}}$ was explained as concentration increase of parathyroid hormone related peptide $(\mathrm{PTHrP})$ secreted from the cancer cells by assuming that PTHrP has no action to Ca channels in cells.

However, the PTH receptors bind both PTH and PTHrP with high structural homology. PTH is a single chain polypeptide that comprises 84 amino acids [7]. PTHrP mainly consists of fragments of great variety, although there are intact forms such as PTHrP1-139 [7]. Both PTH and PTHrP are expected to have the same action in cells by the high homology in their structure and their binding with the receptors. Both functional homology and antagonism between PTH and PTHrP have been studied and still remain an important issue [8]. Here, the unique concentration variations of elements in hair due to breast cancer will be explained as a competitive process between PTH and PTHrP having greatly different dwell times on their common receptors. The purpose of the present paper is to clarify why cancer in the initial stage can be detected by the hair analysis and to establish the hair analysis as a new diagnosis for cancer.

\section{Samples and method}

All the hair and blood samples were collected after informed consent was obtained at the related hospitals and the departments in accordance with ethical standards. Some of the samples were used in the previous work [5].

$\mathrm{X}$-ray fluorescence analysis (XFA) of the hair samples was carried out using synchrotron radiation at the Photon Factory (PF) BL4A beamline in the same way as the previous paper [5]. Excitation energy was $17.4 \mathrm{keV}(0.71 \AA)$. The hair was suspended into the X-ray beam in vacuum. Since hair grows with a rate of $1 \mathrm{~cm}$ per month, time variation of concentration can be observed by scanning along a hair strand. To observe frequent transients between the upper and lower levels of hair [Ca], a focussing beam with a width of $50 \mu \mathrm{m}$ was used. This width corresponds to hair growth for 4 hours. For all other analyses (Figs 2-7) a beam size of $0.5 \times 1.4 \mathrm{~mm}$ was used, corresponding to 5 days of hair growth.

\section{Concentration relations between serum and hair}

The relations between the apparent elemental concentrations in dried serum and hair were given in the previous paper [6]. The results are summarized here. 
Generally, an element $\mathrm{X}$ in serum exists in two phases as atoms in or bound to the protein molecules and as ions in the liquid. The total concentration $[\mathrm{X}]_{\mathrm{S}}$ in dried serum is expressed as,

$$
[\mathrm{X}]_{\mathrm{S}}=[\mathrm{X}]_{\mathrm{I}}+[\mathrm{X}]_{\mathrm{P}}
$$

where $[X]_{I}$ and $[X]_{P}$ are derived from serum $X$ ions and $X$ atoms in serum protein, respectively. By the principle of the inflow-outflow equality, hair $[\mathrm{X}]_{\mathrm{H}}$ concentrations are divided into two levels depending on whether the ion channels of element X are gating or closing in the "hair-making cells" (HM cells) of hair root. The nomenclature for concentration of element $\mathrm{X}$ is listed as follows:

$[\mathrm{X}]_{\mathrm{S}}$ is the concentration in dried serum.

$[\mathrm{X}]_{\mathrm{P}}$ is the protein-bound concentration in dried serum, after subtracting the $\mathrm{X}$ ions.

$[\mathrm{X}]_{\mathrm{I}}$ is the ion concentration given by $[\mathrm{X}]_{\mathrm{I}}=[\mathrm{X}]_{\mathrm{S}}-[\mathrm{X}]_{\mathrm{P}}$.

$[\mathrm{X}]_{\mathrm{H}}$ is the concentration in hair.

$[\mathrm{X}]_{\mathrm{HO}}$ is the hair concentration in the case of the gating (open) ion channels of cells.

$[\mathrm{X}]_{\mathrm{HC}}$ is the hair concentration in the case of the closing ion channels of cells.

To obtain $[\mathrm{X}]$ independently of specimen thickness, we use the relative concentrations defined by

$$
\log [\mathrm{X}]=\log P-\log S=\log (P / S),
$$

where $P$ is the XFA peak height for element $\mathrm{X}$, and $S$ is the background due to X-rays scattered by the sample in FXA. The relations between $[\mathrm{X}]_{\mathrm{H}}$ and $[\mathrm{X}]_{\mathrm{S}}$ obtained in the previous paper [6] are listed in Table 1.

The main element Ca has its standard of $\log [\mathrm{X}]_{\mathrm{P}}=\log [\mathrm{X}]_{\mathrm{H}}=\log P-\log S=\log 10$, and, similarly, the observed value $\log [\mathrm{Cu}]_{\mathrm{H}}=[\log P-\log S]_{\mathrm{H}}$ is normalized so as to have the standard $[\mathrm{Cu}]_{\mathrm{H}}=10$ by

$$
\log [\mathrm{Cu}]_{\mathrm{H}}=[\log P-\log S]_{\mathrm{H}} /\left([\log P-\log S]_{\mathrm{S}}\right)_{\mathrm{st}},
$$

using the standard $\left([\log P-\log S]_{\mathrm{S}}\right)_{\text {st }}$ for dried serum.

There are many kinds of ion channels and receptors, possibly including ones presently unknown. Some of the receptors are associated with channel gating. For the $\mathrm{Ca}^{2+}$ ions, the signaling and PTHoperated channels are different, and the $\mathrm{Ca}$ upper level $[\mathrm{Ca}]_{\mathrm{HO}}$ is probably associated with gating of L-type channels. Furthermore, sulphate ion channels have not yet been reported, although the upper $[\mathrm{S}]_{\mathrm{HO}}$ and lower $[\mathrm{S}]_{\mathrm{HC}}$ level of hair were observed [6]. (The XF method does not discriminate among $\mathrm{S}$ species.) Therefore, this work is a phenomenological study without identifying what kinds of ion channels and receptors are involved. In the basic concept, the channel gating takes place to produce a short pulsed inflow into the cell each time when the messenger protein binds with one of the associated receptors of the cell. This event occurs so frequently with a high concentration of the messenger protein as to accumulate the ion inflows so that the intracellular ion concentration $[\mathrm{X}]_{\mathrm{Cl}}$ reaches the serum ion concentration $[\mathrm{X}]_{\mathrm{I}}$. Since the $[\mathrm{X}]_{\mathrm{CI}}$ is kept at the serum $[\mathrm{X}]_{\mathrm{I}}$ by the channel flow, we have the $[\mathrm{X}]_{\mathrm{HO}}$ determined by $[\mathrm{X}]_{\mathrm{I}}$, as seen in Table 1 .

\section{PTH processes with Ca deficiency}

Ca deficiency observed by the hair analysis has been classified into 4 types [6]: "EE type" as the normal (Ca Ever Enough to have the normal hair $[\mathrm{Ca}]_{\mathrm{H}}=10$ with closing $\mathrm{Ca}^{2+}$ channels in membrane), "DA type" having a $[\mathrm{Ca}]_{\mathrm{H}} \lesssim 10$ with Ca Deficiency to deviate toward Acidosis $[\mathrm{Cl}]_{\mathrm{H}}=[\mathrm{Br}]_{\mathrm{H}}>10$, "DO type" with Ca Deficiency having an Overplus $[\mathrm{Ca}]_{\mathrm{H}}=[\mathrm{Sr}]_{\mathrm{H}} \gtrsim 10($ Ca channel closing $)$ and $[\mathrm{Cl}]_{\mathrm{H}}=$ 
Table 1

Relations between hair $[\mathrm{X}]_{\mathrm{H}}$ and dried serum $[\mathrm{X}]_{\mathrm{S}}$ of element $\mathrm{X}$ defined by Eq. (2)

\begin{tabular}{|c|c|c|c|c|}
\hline$[\mathrm{Fe}]_{\mathrm{S}}=[\mathrm{Fe}]_{\mathrm{P}}$ & {$[\mathrm{Fe}]_{\mathrm{H}}=[\mathrm{Fe}]_{\mathrm{P}}=15$} & (3) & & \\
\hline$[\mathrm{Cu}]_{\mathrm{S}}=[\mathrm{Cu}]_{\mathrm{P}}$ & {$[\mathrm{Cu}]_{\mathrm{H}}=[\mathrm{Cu}]_{\mathrm{P}}=20$} & (4) & & \\
\hline$[\mathrm{Zn}]_{\mathrm{S}}=[\mathrm{Zn}]_{\mathrm{P}}$ & {$[\mathrm{Zn}]_{\mathrm{H}}=[\mathrm{Zn}]_{\mathrm{P}}^{2}=400$} & (5) & & \\
\hline$[\mathrm{S}]_{\mathrm{P}}=[\mathrm{S}]_{\mathrm{I}}$ & {$[\mathrm{S}]_{\mathrm{HC}}=[\mathrm{S}]_{\mathrm{P}}=20$} & (6) & {$[\mathrm{S}]_{\mathrm{HO}}=(1 / 2)[\mathrm{S}]_{\mathrm{I}}^{2}=200$} & (7) \\
\hline$[\mathrm{Ca}]_{\mathrm{P}}=[\mathrm{Ca}]_{\mathrm{I}}$ & {$[\mathrm{Ca}]_{\mathrm{HC}}=[\mathrm{Ca}]_{\mathrm{P}}=10$} & $(8)$ & {$[\mathrm{Ca}]_{\mathrm{HO}}=(1 / 2)[\mathrm{Ca}]_{\mathrm{I}}^{2}=50$} & (9) \\
\hline$[\mathrm{Sr}]_{\mathrm{P}}=[\mathrm{Sr}]_{\mathrm{I}}$ & {$[\mathrm{Sr}]_{\mathrm{HC}}=[\mathrm{Sr}]_{\mathrm{P}}=10$} & (10) & {$[\mathrm{Sr}]_{\mathrm{HO}}=(1 / 2)\left\{[\mathrm{Sr}]_{\mathrm{P}}+[\mathrm{Sr}]_{\mathrm{I}}\right\}^{2}=200$} & (11) \\
\hline$[\mathrm{Cl}]_{\mathrm{P}}=0.04[\mathrm{Cl}]_{\mathrm{I}}$ & {$[\mathrm{Cl}]_{\mathrm{HC}}=[\mathrm{Cl}]_{\mathrm{P}}=10$} & (12) & {$[\mathrm{Cl}]_{\mathrm{HO}}=\left\{2[\mathrm{Cl}]_{\mathrm{I}}\right\}^{1 / 2}=22$} & (13) \\
\hline $\begin{array}{l}{[\mathrm{Br}]_{\mathrm{P}}=0.04[\mathrm{Br}]_{\mathrm{I}}} \\
{[\mathrm{K}]_{\mathrm{S}}=[\mathrm{K}]_{\mathrm{I}}}\end{array}$ & $\begin{array}{l}{[\mathrm{Br}]_{\mathrm{HC}}=[\mathrm{Br}]_{\mathrm{P}}=10} \\
{[\mathrm{~K}]_{\mathrm{HC}}=7.1[\mathrm{~K}]_{S}=300}\end{array}$ & $\begin{array}{l}(14) \\
(16)\end{array}$ & {$[\mathrm{Br}]_{\mathrm{HO}}=\left\{2[\mathrm{Br}]_{\mathrm{I}}\right\}^{1 / 2}=22$} & (15) \\
\hline$[\mathrm{P}]_{\mathrm{P}}=[\mathrm{P}]_{\mathrm{I}}=(1 / 4)[\mathrm{P}]_{\mathrm{S}}$ & {$[\mathrm{P}]_{\mathrm{HC}} \geqslant 10$} & (17) & {$[\mathrm{P}]_{\mathrm{HO}}=5[\mathrm{P}]_{\mathrm{I}}^{1 / 2}=5$} & (18) \\
\hline \multicolumn{5}{|c|}{$\begin{array}{l}{[\mathrm{X}]_{\mathrm{S}} \text { is the concentration in dried serum. }} \\
{[\mathrm{X}]_{\mathrm{P}} \text { is the protein-bound concentration in dried serum, after subtracting the } \mathrm{X} \text { ions. }} \\
{[\mathrm{X}]_{\mathrm{I}} \text { is the ion concentration given by }[\mathrm{X}]_{\mathrm{I}}=[\mathrm{X}]_{\mathrm{S}}-[\mathrm{X}]_{\mathrm{P}} \text {. }} \\
{[\mathrm{X}]_{\mathrm{H}} \text { is the concentration in hair. }} \\
{[\mathrm{X}]_{\mathrm{HO}} \text { is the hair concentration in the case of the gating (open) ion channels of cells. }} \\
{[\mathrm{X}]_{\mathrm{HC}} \text { is the hair concentration in the case of the closing ion channels of cells. }}\end{array}$} \\
\hline
\end{tabular}

$[\mathrm{Br}]_{\mathrm{H}}<10$ (a deviation to alkalosis) by bone resorption, "DE type" having Ca Deficiency for Excitation of channel gating, causing intermittent channel closing and gating, and "LD type" with Long-term Ca Deficiency to continue $\mathrm{Ca}$ channels gating.

Ca sufficiency produces the hair normal $[\mathrm{Ca}]_{\mathrm{H}}=10$ of Eq. (8) in Table 1. Both the ranges of $[\mathrm{Ca}]_{\mathrm{H}}$ $\lesssim 10$ and $[\mathrm{Ca}]_{\mathrm{H}} \gtrsim 10$ are due to Ca deficiency with deviations toward acidosis and alkalosis, respectively [6]. In a range of [Ca $]_{\mathrm{H}} \lesssim 10$ (by PTH), store-operated Ca channel gating occurs so as to adjust the intracellular $\left[\mathrm{Ca}^{2+}\right]$ for maintaining the normal $[\mathrm{Ca}]_{\mathrm{H}}=10$. In this case, hepatocytes and erythrocytes act properly to make $[\mathrm{Cu}]_{\mathrm{H}}$ and $[\mathrm{Ti}]_{\mathrm{H}}$ normal and to keep the equality of $[\mathrm{Cl}]_{\mathrm{H}}=[\mathrm{Br}]_{\mathrm{H}}($ simple deviation of serum $\mathrm{pH}$ ), respectively. $\mathrm{DE}$ and LD types have a $[\mathrm{Ca}]_{\mathrm{H}} \sim 50$ near or at the upper level with $\mathrm{PTH}$-operated $\mathrm{Ca}$ channel gating and show abnormally high $[\mathrm{Cu}]_{\mathrm{H}}$ and/or $[\mathrm{Ti}]_{\mathrm{H}}$ and the inequality $[\mathrm{Cl}]_{\mathrm{H}}<[\mathrm{Br}]_{\mathrm{H}}$ (disordered chloride shift). For the $\mathrm{Cl}$ deficiency (alkalosis), there are two types of relation between $\mathrm{Cl}$ and $\mathrm{Br}$; one is "compensation type" with the $\mathrm{Cl}$ deficiency accompanied by $\mathrm{Br}$ increase $\left([\mathrm{Cl}]_{\mathrm{H}}<10<[\mathrm{Br}]_{\mathrm{H}}\right)$, and the other "independent type" keeping the normal $[\mathrm{Br}]\left([\mathrm{Cl}]_{\mathrm{H}}<[\mathrm{Br}]_{\mathrm{H}}=\right.$ 10) $[6]$.

\subsection{Store-operated Ca channel gating}

Using the 50- $\mu \mathrm{m}$-wide excitation beam, a hair root was analyzed with an interval of $50 \mu \mathrm{m}$ along the hair shaft as shown in Fig. 1. As time progresses from right to left, the higher $[\mathrm{Ca}]_{\mathrm{H}}$ is decreasing toward and then maintaining the normal $[\mathrm{Ca}]_{\mathrm{H}}=10$, with variation of $[\mathrm{Sr}]_{\mathrm{H}}$. Since the inequality $[\mathrm{Ca}]_{\mathrm{H}}<$ $[\mathrm{Sr}]_{\mathrm{H}}$ is produced by Ca channel gating $\left([\mathrm{Ca}]_{\mathrm{H}}=[\mathrm{Sr}]_{\mathrm{H}}\right.$ for channel closing), it is seen that the channel gating takes place for the continuation of $[\mathrm{Ca}]_{\mathrm{H}}=10$ by an internal signal in the $\mathrm{HM}$ cell, i.e., storeoperated Ca channel gating. During the period of $[\mathrm{Ca}]_{\mathrm{H}}=10$, the $[\mathrm{P}]_{\mathrm{H}}$ is at the upper level and the $[\mathrm{Cl}]_{\mathrm{H}}$ is low $\left([\mathrm{Cl}]_{\mathrm{H}}=[\mathrm{Br}]_{\mathrm{H}}<10\right)$ indicating bone resorption and $\left[\mathrm{Ca}^{2+}\right]$ overplus in serum (DO type) [6]. The factors keeping $[\mathrm{K}]_{\mathrm{H}}$ normal and improving $[\mathrm{S}]_{\mathrm{H}}$ to the normal level are due to the adjustment of intracellular $\left[\mathrm{Ca}^{2+}\right]$ by the store-operated channel gating.

Such store-operated $\mathrm{Ca}$ channel gating occurs also for DA type having $[\mathrm{Ca}]_{\mathrm{H}}<8[6]$ without bone resorption $\left([\mathrm{P}]_{\mathrm{H}} \sim 5\right)$. There are many cases of $[\mathrm{Ca}]_{\mathrm{H}}<<10$ where the normal $[\mathrm{Ca}]_{\mathrm{H}}=10$ is not achieved even with store-operated channel gating. 


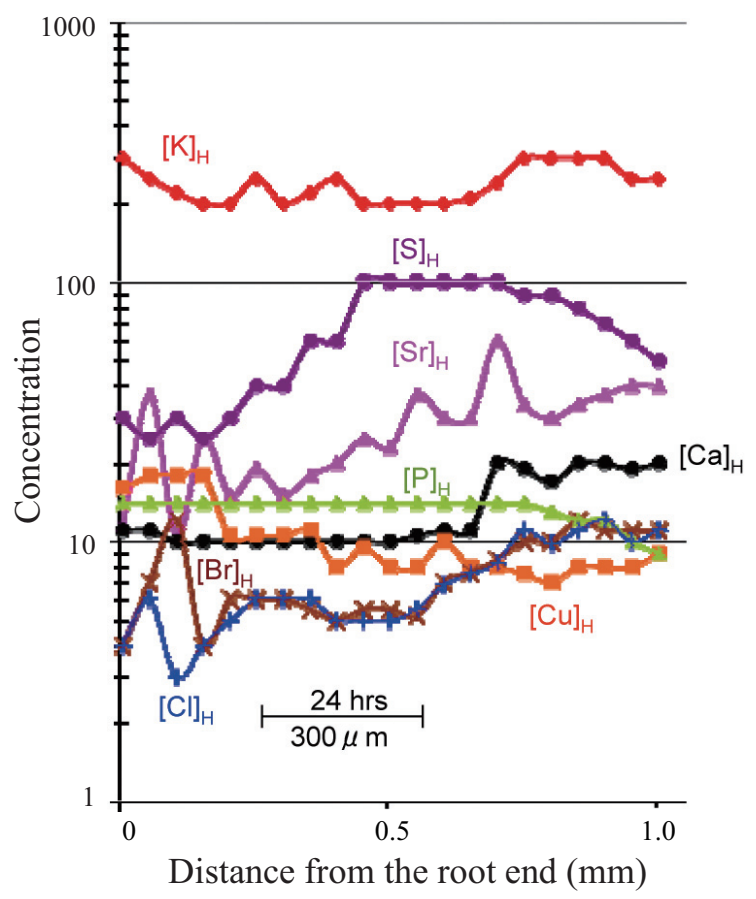

Fig. 1. Store-operated Ca channel gating observed for a male subject by XFA using a 50- $\mu$ m-wide excitation beam. As time progresses from right to left, the higher $[\mathrm{Ca}]_{\mathrm{H}}$ is decreasing and then keeping the normal $[\mathrm{Ca}]_{\mathrm{H}}=10$ with variation of $[\mathrm{Sr}]_{\mathrm{H}}$ by $\mathrm{Ca}$ channel gating. The deviation toward alkalosis with $[\mathrm{Cl}]_{\mathrm{H}}=[\mathrm{Br}]_{\mathrm{H}}<10$ indicates bone resorption with the upper level $[\mathrm{P}]_{\mathrm{H}}$ $\gtrsim 10$. $[\mathrm{K}]_{\mathrm{H}}$ is kept at the normal $[\mathrm{K}]_{\mathrm{H}} \sim 300$, and $[\mathrm{S}]_{\mathrm{H}}$ is decreasing toward the normal $[\mathrm{S}]_{\mathrm{H}}=20$. The $[\mathrm{Cu}]_{\mathrm{H}}$ is shown with the normalized values by Eq. (2N). (Colours are visible in the online version of the article; http://dx.doi.org/10.3233/XST-140447)

\subsection{LD type: PTH-operated Ca channel gating}

LD type is a chronic Ca deficiency having Ca channel gating for a long term. Typical examples are shown with two female subjects in Fig. 2. A single hair strand from each was analysed from root to tip; hair $[\mathrm{Ca}]_{\mathrm{H}}$ and $[\mathrm{Sr}]_{\mathrm{H}}$ gradually increase with distance from the root and reach their upper levels, $[\mathrm{Ca}]_{\mathrm{H}}=$ 50 and $[\mathrm{Sr}]_{\mathrm{H}}=200$ (See Table 1), respectively, and these levels in the tip part correspond to chronic $\mathrm{Ca}$ deficiency (for more than 6 months). Each of the $[\mathrm{Ca}]_{\mathrm{H}}$ and $[\mathrm{Sr}]_{\mathrm{H}}$ profiles is the same for both the subjects; by moving one of them horizontally, they can be superimposed.

The $[\mathrm{Sr}]_{\mathrm{H}}$ and $[\mathrm{Ca}]_{\mathrm{H}}$ curves are parallel to each other in all the range of the variation from the lower to upper level. Their vertical distance is given by Eq. (11)-Eq. (9) from Table 1, i.e.,

$$
\log [\mathrm{Sr}]_{\mathrm{HO}}-\log [\mathrm{Ca}]_{\mathrm{HO}}=2 \log \left\{1+[\mathrm{Sr}]_{\mathrm{P}} /[\mathrm{Sr}]_{\mathrm{I}}\right\}=\log 4
$$

using $\log [\mathrm{Sr}]_{\mathrm{I}}=\log [\mathrm{Ca}]_{\mathrm{I}}$ by the definition of Eq. (2), the proportionality of [Sr] with [Ca] and $[\mathrm{Sr}]_{\mathrm{P}} \sim[\mathrm{Sr}]_{\mathrm{I}}$. This distance in a logarithmic scale is equivalent to a ratio of $[\mathrm{Sr}]_{\mathrm{H}} /[\mathrm{Ca}]_{\mathrm{H}}=4$. As seen from Fig. 2, the ratio is kept at

$$
[\mathrm{Sr}]_{\mathrm{H}} /[\mathrm{Ca}]_{\mathrm{H}}=[\mathrm{Sr}]_{\mathrm{HO}} /[\mathrm{Ca}]_{\mathrm{HO}}=4
$$

in the entire range of the concentration change except the vicinity of the root where $[\mathrm{Ca}]_{\mathrm{H}}=[\mathrm{Sr}]_{\mathrm{H}} \sim 10$ at recovery. Hereafter, the value of $\log [\mathrm{Sr}]_{\mathrm{H}}-\log [\mathrm{Ca}]_{\mathrm{H}}$ will be referred to as a "Sr/Ca ratio".

Figure 2 shows that the recovery from the upper to lower level of $[\mathrm{Ca}]_{\mathrm{H}}$ takes 10 months. This 10 month decay might suggest a large amount of $\mathrm{Ca}$ and $\mathrm{Sr}$ accumulated in the $\mathrm{HM}$ cells thorough their 


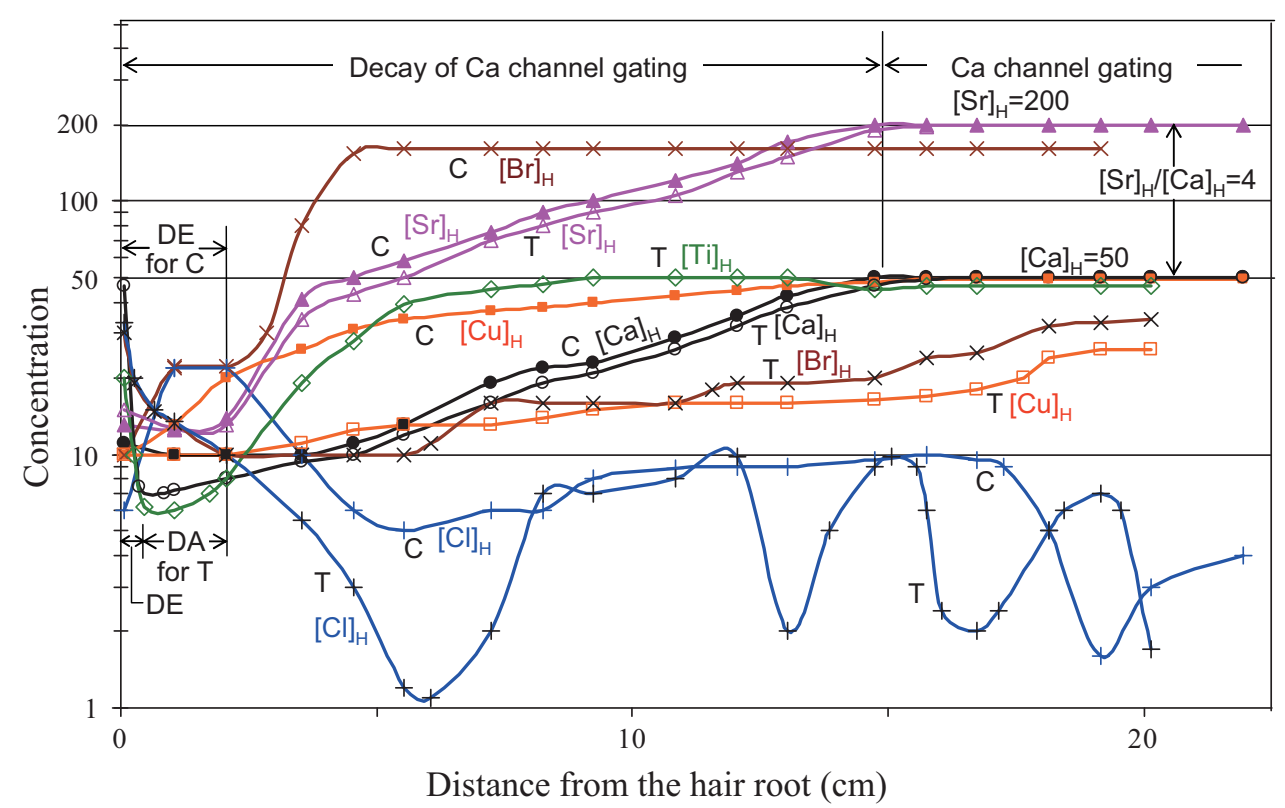

Fig. 2. Process of long-term Ca deficiency (LD type) observed along a single hair strand for the two females labelled "C" and " $\mathrm{T}$ " (ages of 41 and 39). In the tip part, the upper level $[\mathrm{Ca}]_{\mathrm{H}}=50$ continues for more than 6 months by the Ca inflow into the cells through gaiting Ca channels. Then, the $[\mathrm{Ca}]_{\mathrm{H}}$ decreases toward the lower level with the common form "10-month decay" by a slow decrease in gating frequency caused by the gradual decrease of serum $[\mathrm{PTH}]$. The $[\mathrm{Ca}]_{\mathrm{H}}$ and $[\mathrm{Sr}]_{\mathrm{H}}$ curves are parallel with a vertical distance of $\log [\mathrm{Sr}]_{\mathrm{H}}-\log [\mathrm{Ca}]_{\mathrm{H}}=\log \left([\mathrm{Sr}]_{\mathrm{H}} /[\mathrm{Ca}]_{\mathrm{H}}\right)=\log 4$ in all the range of $[\mathrm{Ca}]_{\mathrm{H}}>10$. The liver function to excrete excess $\mathrm{Cu}$ or Ti into bile is deteriorated by the $\mathrm{Ca}$ inflows into the hepatocytes; $[\mathrm{Cu}]_{\mathrm{H}}$ remains high, and $[\mathrm{Ti}]_{\mathrm{H}}$ is at the noise level for "C" (LD-Cu type), while "T" (LD-Ti type) has higher $[\mathrm{Ti}]_{\mathrm{H}}$ in comparison with $[\mathrm{Cu}]_{\mathrm{H}}$. Both have the alkalosis of compensation type with $[\mathrm{Cl}]_{\mathrm{H}}<10<[\mathrm{Br}]_{\mathrm{H}}$ and change to $\mathrm{DE}$ type with $[\mathrm{Cl}]_{\mathrm{H}}=[\mathrm{Br}]_{\mathrm{H}}$ at the end of the process near the root. The $[\mathrm{Cu}]_{\mathrm{H}},[\mathrm{Ti}]_{\mathrm{H}},[\mathrm{Cl}]_{\mathrm{H}}$ and $[\mathrm{Br}]_{\mathrm{H}}$ start to recover after the $[\mathrm{Ca}]_{\mathrm{H}}$ decreases to the normal. Note that "T" shows an abrupt transition to the $\mathrm{Ca}$ upper level at the root. The $[\mathrm{Cu}]_{\mathrm{H}}$ is shown with the normalization by Eq. $(2 \mathrm{~N})$. (Colours are visible in the online version of the article; http://dx.doi.org/10.3233/XST-140447)

long-lasting ion channel gating. However, it was found that Ca supplementation (Ca $900 \mathrm{mg} / \mathrm{day}$ for 10 days) $[5]$ in the LD-type process made hair $[\mathrm{Ca}]_{\mathrm{H}}$ to decrease to less than the standard $[\mathrm{Ca}]_{\mathrm{HC}}<$ 10 by closing the $\mathrm{Ca}$ channels. Therefore, the $\mathrm{Ca}$ accumulation in the body is not responsible for the 10-month decrease. It is more likely due to a slow decrease in the frequency of Ca channel gating by gradual decrease of serum [PTH].

The $\mathrm{Ca}$ inflow into cells in LD type has various effects on cell functions. Most of metal elements are under homeostatic control by the liver which excretes their excess into bile. This function is decreased by the $\mathrm{Ca}$ channel inflows into the hepatocytes. In fact, together with $[\mathrm{Ca}]_{\mathrm{H}}$ at the upper level, many small peaks of various metals $(\mathrm{Cr}, \mathrm{Ni}, \mathrm{Mn}, \mathrm{Pb}$, etc.) appear in the XFA spectra of hair, although not seen here for EE and DA types. Among them, very high $[\mathrm{Cu}]_{\mathrm{H}}$ and/or $[\mathrm{Ti}]_{\mathrm{H}}$ values are seen with $[\mathrm{Ca}]_{\mathrm{H}}=50$ and $[\mathrm{Sr}]_{\mathrm{H}}=200$; they are referred to as "LD-Cu type" and "LD-Ti type" labelled "C" and "T" in Fig. 2. Both the subjects have fatty liver caused by the long-lasting $\mathrm{Ca}(\mathrm{Sr})$ inflows into the cells (adipocytes [4]).

LD-type subjects are in alkalosis with the inequality $[\mathrm{Cl}]<[\mathrm{Br}][6]$. In Fig. 2, both the subjects are a "compensation type"; the LD-Cu type labelled "C" maintains a large separation of $[\mathrm{Cl}]_{\mathrm{H}}$ and $[\mathrm{Br}]_{\mathrm{H}}$, $[\mathrm{Cl}]_{\mathrm{H}} \leqslant 10$ vs. $[\mathrm{Br}]_{\mathrm{H}}=160$, in all the decay process from the duration of $[\mathrm{Ca}]_{\mathrm{H}}=50$ to the normal value $[\mathrm{Ca}]_{\mathrm{H}}=10$. The high $[\mathrm{Br}]_{\mathrm{H}}$ value is due to compensation for the $\mathrm{Cl}$ deficiency, and $[\mathrm{Br}]_{\mathrm{H}}=$ 160 is calculated to correspond to about $1 \%$ of the normal $[\mathrm{Cl}]_{\mathrm{I}}$, although it is far from the complete compensation. Near the root, when $[\mathrm{Ca}]_{\mathrm{H}}$ recovers to the normal value, the equality $[\mathrm{Cl}]_{\mathrm{H}}=[\mathrm{Br}]_{\mathrm{H}}$ 


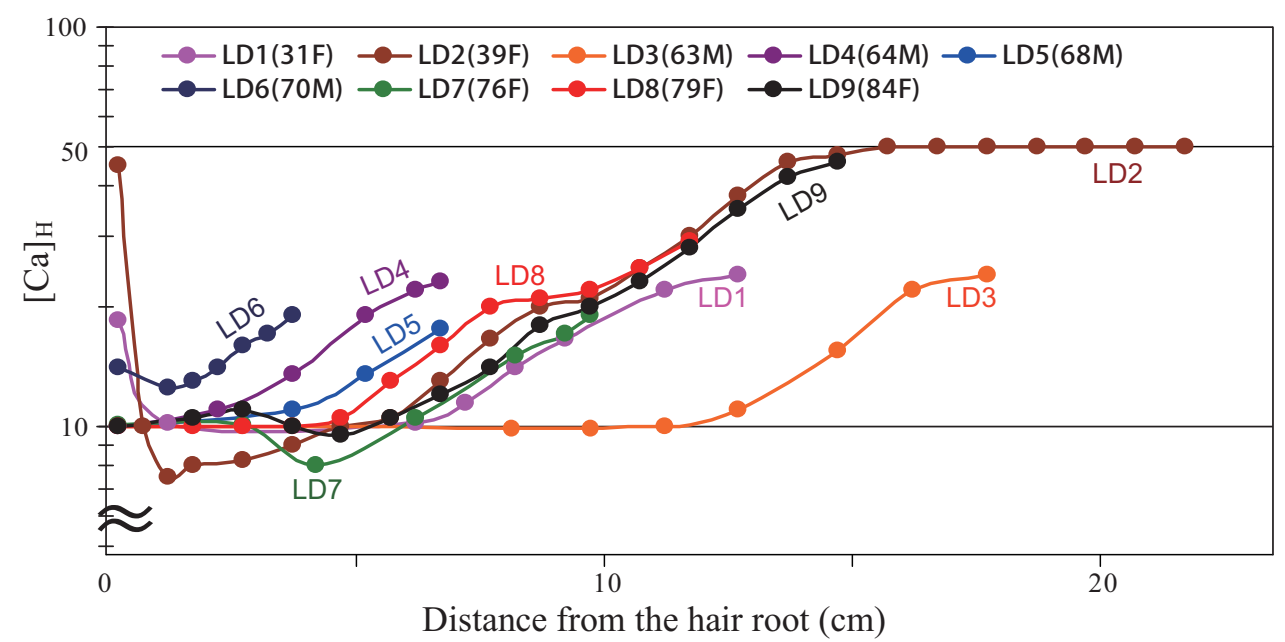

Fig. 3. The $[\mathrm{Ca}]_{\mathrm{H}}$ profiles observed for LD-type subjects with the long-term Ca deficiency. Although most of the hair samples are too short to observe the entire process, they have the same decay form, independently of ages. In the bracket of each label, the number indicates age, and $\mathrm{M}$ and $\mathrm{F}$ stand for the sexes. LD type, in many cases, has a long-term cycle of [Ca $]_{\mathrm{H}}$ to repeat a series of the $[\mathrm{Ca}]_{\mathrm{H}}$ upper level, "10-month decay" to the normal lower level, and abrupt transition to the upper level via a DE type for a new cycle. (Colours are visible in the online version of the article; http://dx.doi.org/10.3233/XST-140447)

appears at the $\mathrm{Cl}(\mathrm{Br})$ upper level [Eqs (13) and (15) in Table 1] (low [Cl] in serum). The long-term lasting inequality of $[\mathrm{Cl}]_{\mathrm{H}}<<[\mathrm{Br}]_{\mathrm{H}}$ indicates that almost all the process is due to Ca channel gating by the serum PTH.

The LD-Ti type labelled "T" also shows a similar process with a separation of $[\mathrm{Br}]_{\mathrm{H}}$ and $[\mathrm{Cl}]_{\mathrm{H}}$, though their levels are lower. In the region of about 2 months near the root, the $[\mathrm{Ca}]_{\mathrm{H}}$ is less than the normal, and $[\mathrm{Cl}]_{\mathrm{H}}$ exceeds the normal level with $[\mathrm{Cl}]_{\mathrm{H}}=[\mathrm{Br}]_{\mathrm{H}}$, indicating DA type $[5,6]$. At the root, the $[\mathrm{Ca}]_{\mathrm{H}}$ increases abruptly toward the upper level by Ca channel gating, again.

The decay profiles of $[\mathrm{Ca}]_{\mathrm{H}}$ are common among LD-type subjects, independent of age, as seen from 9 subjects in an age range of 31 84 in Fig. 3. Although most of the hair is not long enough to observe the entire of decay curves, it is seen that all have the nearly equal gradient; although $[\mathrm{Sr}]_{\mathrm{H}}$ is not shown in Fig. 3, the decay process was confirmed to have the ratio of $[\mathrm{Sr}]_{\mathrm{H}} /[\mathrm{Ca}]_{\mathrm{H}}=4$ and the inequality $[\mathrm{Cl}]_{\mathrm{H}}<$ $[\mathrm{Br}]_{\mathrm{H}}$ seen in alkalosis. Two of the subjects show abrupt transition of $[\mathrm{Ca}]_{\mathrm{H}}$ from the lower to upper level near the roots.

It is concluded from Figs 2 and 3 that LD type is a long-period cycle of Ca channel gating and closing with the 10-month decay in serum [PTH]. The $\mathrm{Ca}$ inflow into cells through the long-lasting Ca channel gating gradually relieves the Ca deficiency and decreases serum [PTH]. After recovering to the normal, Ca deficiency starts again with a DA type and then proceeds further to give rise PTH-operated Ca channel gating, and a new LD type.

The chronic Ca deficiency in LD type is probably due to slow bone resorption; if it responses to $\mathrm{Ca}$ deficiency quickly, Ca channel gating should not take place and result in DA type, instead of LD type. As will be described later, the upper level of $[\mathrm{Ca}]_{\mathrm{H}}$ has a risk for cancer generation.

\section{Processes with PTHrP from breast cancer}

Calcified lesions are detected for breast cancer by X-ray mammography. Therefore, hair from patients is expected to reveal a parallel abnormal calcium distribution, or an abnormal Ca metabolism due to 


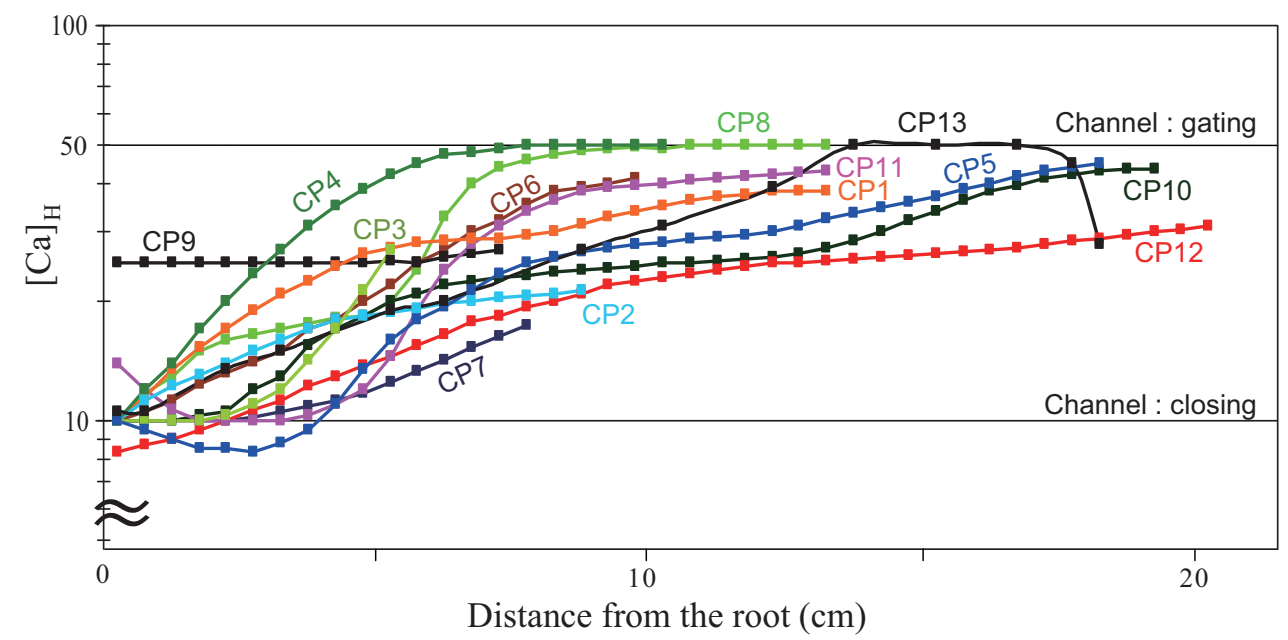

Fig. 4. History of $[\mathrm{Ca}]_{\mathrm{H}}$ observed along single hair strands of breast-cancer patients labelled $\mathrm{CP} 1 \sim \mathrm{CP} 13$. CP13 is that of Fig. 7 as the typical entire process. Cancer is present at the upper level $[\mathrm{Ca}]_{\mathrm{H}}=50$ due to Ca deficiency, and the $[\mathrm{Ca}]_{\mathrm{H}}$ decreases gradually to the lower level with the cancer growth. CP9 having an intermediate $[\mathrm{Ca}]_{\mathrm{H}}$ value between the two levels at the root is a patient with an early cancer detected by a periodic inspection. (Colours are visible in the online version of the article; http://dx.doi.org/10.3233/XST-140447)

cancer. Figure 4 is the result of XFA for hair samples from 13 breast-cancer patients. The hair roots usually show $[\mathrm{Ca}]_{\mathrm{H}}$ values of the lower level at the time of finding cancer; the $[\mathrm{Ca}]_{\mathrm{H}}$ increases with distance from the root and reaches the upper level. It is assumed that the cancer is generated during the term of the upper $[\mathrm{Ca}]_{\mathrm{H}}$ level by PTH-operated $\mathrm{Ca}$ channel gating of cells due to Ca deficiency, and the $[\mathrm{Ca}]_{\mathrm{H}}$ decreases gradually toward the lower level with the cancer growth. The closer the $[\mathrm{Ca}]_{\mathrm{H}}$ value is to the upper level, the earlier the stage of the cancer is; the patient labelled "CP9" had an early cancer detected by a periodic diagnosis, showing an intermediate $[\mathrm{Ca}]_{\mathrm{H}}$ value between the two levels at the root. The observation in Fig. 4 indicates cancer generation from the LD type. In comparison with LD type in Fig. 2, hair from cancer patients shows a variety of $[\mathrm{Ca}]_{\mathrm{H}}$ decay forms, which are due to existence of both PTH and PTHrP in the serum.

\subsection{Long-term process of cancer growth}

A patient happened to have undyed hair 40-cm long, long enough to observe the entire process of breast-cancer recurrence in lymph nodes (after the cancer had been removed by an operation). The $[\mathrm{Sr}]_{\mathrm{H}},[\mathrm{Ca}]_{\mathrm{H}},[\mathrm{Cu}]_{\mathrm{H}},[\mathrm{Cl}]_{\mathrm{H}}$ and $[\mathrm{Br}]_{\mathrm{H}}$ were measured along the single hair sample, as seen in Fig. 5. The hair tip is of a DE type, and the hair $[\mathrm{Sr}]_{\mathrm{H}}$ and $[\mathrm{Ca}]_{\mathrm{H}}\left([\mathrm{Cu}]_{\mathrm{H}}\right)$ have a steep increase to their upper level from lower level. This upper level of an $\mathrm{LD}-\mathrm{Cu}$ type is kept at $[\mathrm{Ca}]_{\mathrm{H}}=50$ for the initial two months, lasting further for about 8 months with a slightly lower $[\mathrm{Ca}]_{\mathrm{H}}$. This term is referred to as "LD-like" for convenience sake and is followed by parallel decay of $[\mathrm{Ca}]_{\mathrm{H}}$ and $[\mathrm{Cu}]_{\mathrm{H}}$ differently from LD type (Fig. 2). Then, a long plateau at an intermediate $\mathrm{Ca}$ level is seen for about 12 months, and the $[\mathrm{Ca}]_{\mathrm{H}}$ decreases further toward the lower level.

$\mathrm{The} \mathrm{Sr} / \mathrm{Ca}$ ratio is the most important factor that distinguishes between LD type and cancer. When all the cells have $\mathrm{Ca}$ channel gating by $\mathrm{PTH}$, we have $[\mathrm{Ca}]_{\mathrm{H}}=50$ and $[\mathrm{Sr}]_{\mathrm{HO}} /[\mathrm{Ca}]_{\mathrm{HO}}=4$ [Eq. (19)]. This state is ready for cancer generation. If all the cells have PTHrP from cancer on their receptors with a long dwell time as will be measured later, $\mathrm{Ca}$ channel gating frequency becomes so negligible as to 


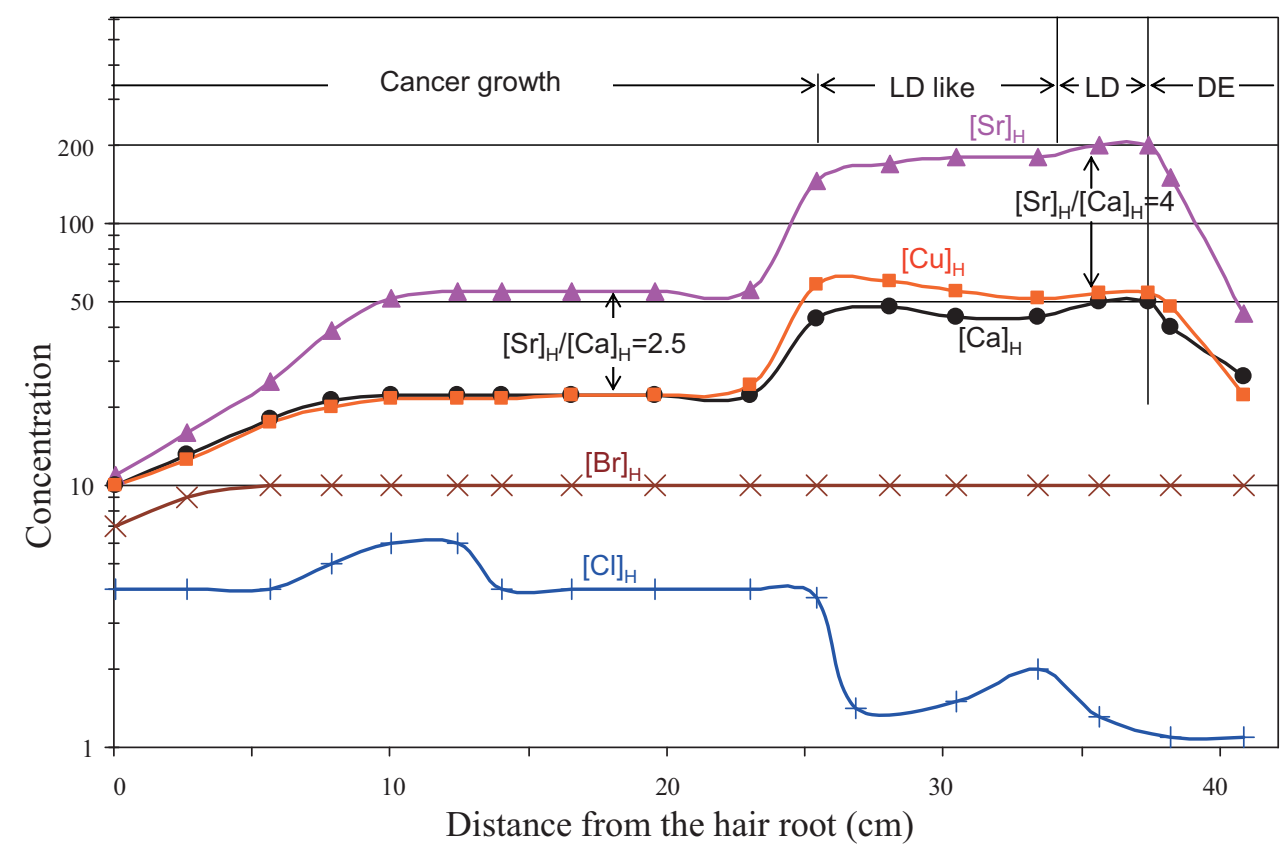

Fig. 5. Recurrence in lymph nodes nine years after surgical resection of breast cancer observed as variations of elemental levels along a single hair strand from the patient. At the hair tip, $[\mathrm{Ca}]_{\mathrm{H}}$ transits from the lower level to upper level as a DE type, and then has a 10-month-long term of LD and LD-like type with $[\mathrm{Ca}]_{\mathrm{H}} \sim 50$ and $\log \left[\mathrm{Sr}_{\mathrm{H}}-\log [\mathrm{Ca}]_{\mathrm{H}}=\log \left([\mathrm{Sr}]_{\mathrm{H}} /[\mathrm{Ca}]_{\mathrm{H}}\right)=\right.$ $\log 4$. The cancer may initiate the PTHrP secretion between the LD-like and LD type. The increase of the serum [PTHrP] decreases the $\mathrm{Ca}$ inflow rate into the cells by the channel gating; the inflow rate balances with the $\mathrm{Ca}$ excretion rate into the hair growing with $[\mathrm{Ca}]_{\mathrm{H}}=50$ at the end of the LD-like term. With the further growth of the cancer, both the $[\mathrm{Ca}]_{\mathrm{H}}$ and $[\mathrm{Sr}]_{\mathrm{H}} /[\mathrm{Ca}]_{\mathrm{H}}$ decrease. At the plateau region, $70 \%$ of cells have closing ion channels. Note that the recovering of $[\mathrm{Cu}]_{\mathrm{H}}$ and $[\mathrm{Cl}]_{\mathrm{H}}$ (independent type) toward their normal values takes place simultaneously with the $[\mathrm{Ca}]_{\mathrm{H}}$ decay, indicating that the $\mathrm{Ca}$ inflow into hepatocytes and erythrocytes are responsible for their functional deterioration. The $[\mathrm{Cu}]_{\mathrm{H}}$ values normalized by Eq. $(2 \mathrm{~N})$ agree with the $[\mathrm{Ca}]_{\mathrm{H}}$ values, showing their close relation. (Colours are visible in the online version of the article; http://dx.doi.org/10.3233/XST-140447)

be regarded as channel closing, and the ratio turns out to be $[\mathrm{Sr}]_{\mathrm{H}} /[\mathrm{Ca}]_{\mathrm{H}}=1\left([\mathrm{Ca}]_{\mathrm{H}}=[\mathrm{Sr}]_{\mathrm{H}}=10\right)$. Therefore, the cancer process must be $1<[\mathrm{Sr}]_{\mathrm{H}} /[\mathrm{Ca}]_{\mathrm{H}}<4$. This change in ratio can be seen in Fig. 5; the LD and LD-like periods show the ratio $[\mathrm{Sr}]_{\mathrm{H}} /[\mathrm{Ca}]_{\mathrm{H}}=4$, which decreases to $[\mathrm{Sr}]_{\mathrm{H}} /[\mathrm{Ca}]_{\mathrm{H}}=2.5$ in the plateau region. The ratio decreases further and becomes $[\mathrm{Sr}]_{\mathrm{H}} /[\mathrm{Ca}]_{\mathrm{H}}=1.1$ at the root. The ratio decreases with cancer growth.

The unique $[\mathrm{Ca}]_{\mathrm{H}}$ decay form seen in cancer may be attributable to the ratio between the numbers of the cells with gating and closing Ca channels; the plateau level is calculated to be by about $70 \%$ of the total cells having Ca channel closing [See Eq. (20)]. Therefore, deterioration of cell function by the $\mathrm{Ca}$ inflow with $[\mathrm{Ca}]_{\mathrm{H}}=50$ may be reduced from LD type, as seen from the following examples for the $[\mathrm{Cu}]_{\mathrm{H}}$ and $[\mathrm{Cl}]_{\mathrm{H}}$.

In Fig. 5, the $[\mathrm{Cu}]_{\mathrm{H}}$ decreases parallel with the $[\mathrm{Ca}]_{\mathrm{H}}$ decay, differently from LD type. This observation indicates that cancer acts to reduce the deterioration of liver function to excrete excess metals caused by the $\mathrm{Ca}$ inflow into the hepatocytes. The parallel decay of $[\mathrm{Cu}]_{\mathrm{H}}$ and $[\mathrm{Ca}]_{\mathrm{H}}$ implies a close relation between the cell function and intracellular [Ca]. Whereas, the LD-Cu type in Fig. 2 remains at the high $[\mathrm{Cu}]_{\mathrm{H}}$ level until the $[\mathrm{Ca}]_{\mathrm{H}}$ lowers to the normal $[\mathrm{Ca}]_{\mathrm{H}}=10$.

From this point of view, we can expect a similar cancer effect on alkalosis; the patient in Fig. 5 shows an independent-type alkalosis with $[\mathrm{Br}]_{\mathrm{H}}=10$ over the entire process, and it is seen that the $[\mathrm{Cl}]_{\mathrm{H}}$ 

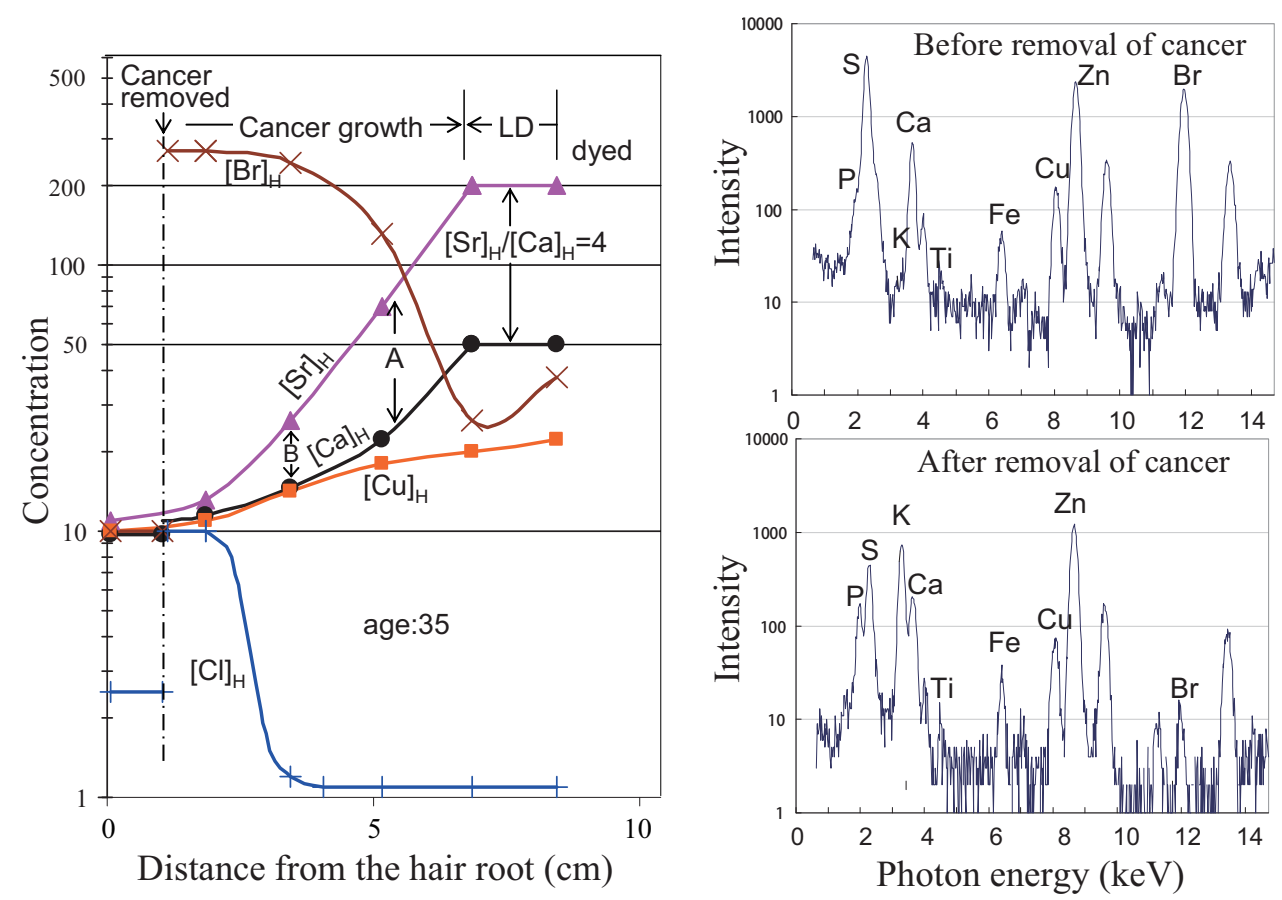

Fig. 6. Rapid growth of breast cancer observed as variations of elemental levels along a single hair strand from the patient. The $\mathrm{Sr} / \mathrm{Ca}$ ratio is $[\mathrm{Sr}]_{\mathrm{H}} /[\mathrm{Ca}]_{\mathrm{H}}=4$ in the hair tip region and decreases rapidly to $[\mathrm{Sr}]_{\mathrm{H}} /[\mathrm{Ca}]_{\mathrm{H}} \sim 1.1$ with cancer growth. (The tip part was dyed and so gave no reliable information). The inequality $[\mathrm{Br}]_{\mathrm{H}}>>[\mathrm{Cl}]_{\mathrm{H}}$ is of the type to compensate the low serum $[\mathrm{Cl}]$ by the high $[\mathrm{Br}]$ (alkalosis). Note that the recovering of $[\mathrm{Cu}]_{\mathrm{H}}$ and $[\mathrm{Cl}]_{\mathrm{H}}$ toward the normal levels takes place simultaneously. $[\mathrm{K}]_{\mathrm{H}}$ was too low to measure. The $[\mathrm{Cu}]_{\mathrm{H}}$ is normalized by Eq. $(2 \mathrm{~N})$. After removing the cancer by an operation, hair Br recovers to $[\mathrm{Br}]_{\mathrm{H}}=10$, but $\mathrm{Cl}$ still remains at $[\mathrm{Cl}]_{\mathrm{H}}=2 \sim 3$. The $\mathrm{FX}$ spectra before and after removal of cancer are shown on the right side. (Colours are visible in the online version of the article; http://dx.doi.org/10.3233/XST-140447)

increases nearly simultaneously with the parallel decay of $[\mathrm{Ca}]_{\mathrm{H}}$ and $[\mathrm{Cu}]_{\mathrm{H}}$ toward the plateau region. This increase of $[\mathrm{Cl}]_{\mathrm{H}}$ by cancer leads to the conclusion that the alkalosis is due to the deterioration of the chloride shift caused by the inflows of $\mathrm{Ca}$ ions into erythrocytes through the gating Ca channels [6].

\subsection{Fast-growing cancer}

In Fig. 6, a typical example of the compensation-type alkalosis can be seen for a breast-cancer patient at the age of 35. Although the hair tip part was compromised by dying and gives no trustworthy information, probably the duration of $[\mathrm{Ca}]_{\mathrm{H}}=50$ and $[\mathrm{Sr}]_{\mathrm{H}}=200$ should be less than a few months. Near the end of the upper $[\mathrm{Ca}]_{\mathrm{H}}$ level, the cancer is assumed to have been generated, and the steep descents of $[\mathrm{Ca}]_{\mathrm{H}}$ and $[\mathrm{Sr}]_{\mathrm{H}}$ start with a ratio of $[\mathrm{Sr}]_{\mathrm{H}} /[\mathrm{Ca}]_{\mathrm{H}}=4$, which is decreased to $[\mathrm{Sr}]_{\mathrm{H}} /[\mathrm{Ca}]_{\mathrm{H}} \sim 1.1$ near the root. The cancer growth is so fast that it takes only 5 months from $[\mathrm{Ca}]_{\mathrm{H}}=50$ to $[\mathrm{Ca}]_{\mathrm{H}}=10$. The $[\mathrm{Br}]_{\mathrm{H}}$ value exceeds its upper level $\left([\mathrm{Br}]_{\mathrm{H}}=22\right)$ and increases rapidly with the cancer growth. In this case $[\mathrm{Cl}]_{\mathrm{H}}$ may be as low as $[\mathrm{Cl}]_{\mathrm{H}} \sim 1$ with no $\mathrm{Cl}$ peak seen beyond the noise level and shows an alkalosis with $[\mathrm{Cl}]_{\mathrm{H}}<10<[\mathrm{Br}]_{\mathrm{H}}$. In the root region, the $[\mathrm{Cl}]_{\mathrm{H}}$ increases rapidly to $[\mathrm{Cl}]_{\mathrm{H}}=10$, and the $[\mathrm{Br}]_{\mathrm{H}}$ reaches $[\mathrm{Br}]_{\mathrm{H}}=280$ which is calculated to compensate about $2 \%$ of the normal serum $[\mathrm{Cl}]_{\mathrm{S}}$. Approaching the root, the alkalosis is reduced as the cancer grows. Because of the compensation type, the reduction in alkalosis is produced by an increase in the sum of $[\mathrm{Cl}]_{\mathrm{H}}+[\mathrm{Br}]_{\mathrm{H}}$. The high $[\mathrm{Br}]_{\mathrm{H}}$ values 
observed in Fig. 6 suggest that $\mathrm{Br}$ in the compensation type can move across the erythrocyte membrane to participate in the chloride shift.

The decay curves of $[\mathrm{Ca}]_{\mathrm{H}}$ and $[\mathrm{Sr}]_{\mathrm{H}}$ are given by the ratio $x$ of the number of cells with closing $\mathrm{Ca}$ channels to the total cell number at the time. Since the proportion of cells with gating channels is $(1-x)$, we have

$$
[\mathrm{Ca}]_{\mathrm{H}}=[\mathrm{Ca}]_{\mathrm{HC}} x+[\mathrm{Ca}]_{\mathrm{HO}}(1-x)
$$

and

$$
[\mathrm{Sr}]_{\mathrm{H}}=[\mathrm{Sr}]_{\mathrm{HC}} x+[\mathrm{Sr}]_{\mathrm{HO}}(1-x),
$$

where $[\mathrm{Ca}]_{\mathrm{HO}}=50$ by Eq. (9), $[\mathrm{Sr}]_{\mathrm{HO}}=200$ by Eq. $(11),[\mathrm{Ca}]_{\mathrm{HC}}=10$ and $[\mathrm{Sr}]_{\mathrm{HC}}=10$ by Eqs $(8)$ and (10) in Table 1.

At the position indicated by the vertical arrow "A" in Fig. 6, the observed curve gives $[\mathrm{Ca}]_{\mathrm{H}}=24$, and then we have $x=0.65$ from $10 x+50(1-x)=24$ by Eq. (20). Using this value of $x$, the $[\mathrm{Sr}]_{\mathrm{H}}$ is calculated by Eq. $(21)$ as $10 \times 0.65+200 \times(1-0.65)=76$, which agrees with the value pointed by Arrow A. Similarly, the $[\mathrm{Ca}]_{\mathrm{H}}=14$ at the position pointed by Arrow B results in $x=0.9$ and $[\mathrm{Sr}]_{\mathrm{H}}=$ 29 in good agreement with the observed value. The cancer process can be described by both Eqs (20) and (21). The decay curve influenced by cancer is due to the ratio between the numbers of cells with closing/gating Ca channels. The observed $x$ value can be used for evaluation of cancer growth.

With $0<x<1$, we have

$$
1<[\mathrm{Sr}]_{\mathrm{H}} /[\mathrm{Ca}]_{\mathrm{H}}<[\mathrm{Sr}]_{\mathrm{HO}} /[\mathrm{Ca}]_{\mathrm{HO}}=4 .
$$

Distinction between LD type and cancer can be made by whether the decay process has $[\mathrm{Sr}]_{\mathrm{H}} /[\mathrm{Ca}]_{\mathrm{H}}=$ 4 or $1<[\mathrm{Sr}]_{\mathrm{H}} /[\mathrm{Ca}]_{\mathrm{H}}<4$. This cancer criterion should be used for a range of $[\mathrm{Ca}]_{\mathrm{H}}>10$, by avoiding the range $[\mathrm{Ca}]_{\mathrm{H}} \lesssim 10$ for store-operated $\mathrm{Ca}$ channel gating.

From Eqs (20) and (21), we have also

$$
\left([\mathrm{Sr}]_{\mathrm{H}}-[\mathrm{Sr}]_{\mathrm{HC}}\right) /\left([\mathrm{Ca}]_{\mathrm{H}}-[\mathrm{Ca}]_{\mathrm{HC}}\right)=\left([\mathrm{Sr}]_{\mathrm{HO}}-[\mathrm{Sr}]_{\mathrm{HC}}\right) /\left([\mathrm{Ca}]_{\mathrm{HO}}-[\mathrm{Ca}]_{\mathrm{HC}}\right) .
$$

Since $[\mathrm{Ca}]_{\mathrm{HC}} \neq 0$ and $[\mathrm{Sr}]_{\mathrm{HC}} \neq 0$, the cancer process recorded in hair is essentially different from that of LD type by Eq. (19).

\subsection{Enhanced serum protein: Immunoglobulin}

An ideal example with a straight decay form in a logarithmic scale was encountered in the hair analysis of a 46-year old breast-cancer patient as shown in Fig. 7. At the hair tip, the $[\mathrm{Ca}]_{\mathrm{H}}$ and $[\mathrm{Sr}]_{\mathrm{H}}$ transition from the lower level to the upper level as a DE type. At this point, the subject was considered to be free from cancer. The upper $[\mathrm{Ca}]_{\mathrm{H}}=50$ level lasts about 4 months. After the upper $[\mathrm{Sr}]_{\mathrm{H}}=200$ level lasting 1.5 months, the $[\mathrm{Sr}]_{\mathrm{H}}$ decreases to have a value of $[\mathrm{Sr}]_{\mathrm{H}} /[\mathrm{Ca}]_{\mathrm{H}}=3$. With the cancer growth, each of the $[\mathrm{Ca}]_{\mathrm{H}}$ and $[\mathrm{Sr}]_{\mathrm{H}}$ decays with a nearly constant gradient, approximated by a straight line. It is seen easily from Fig. 7 that both the $[\mathrm{Ca}]_{\mathrm{H}}$ and $[\mathrm{Sr}]_{\mathrm{H}}$ satisfy the relation of Eq. (22).

The patient in Fig. 7 is classified as having the independent-type alkalosis, and the $[\mathrm{Br}]_{\mathrm{P}}$ should be normal $[\mathrm{Br}]_{\mathrm{P}}=[\mathrm{Br}]_{\mathrm{H}}=10$ even with $\mathrm{Cl}$ deficiency $[\mathrm{Cl}]_{\mathrm{H}}=[\mathrm{Cl}]_{\mathrm{P}}<10$. The result $[\mathrm{Br}]_{\mathrm{H}}<10$ in Fig. 7 means an occurrence of dilution by increase in serum protein concentration. Since the dilution is the same for the $\mathrm{Sr}$, the observed value $[\mathrm{Br}]_{\mathrm{H}}=[\mathrm{Br}]_{\mathrm{P}}=7$ in Fig. 7 gives $[\mathrm{Sr}]_{\mathrm{HO}}=(1 / 2)\left\{[\mathrm{Sr}]_{\mathrm{P}}+[\mathrm{Sr}]_{\mathrm{I}}\right\}^{2}=$ $(7+10)^{2} / 2=150$ by Eq. (11) in good agreement with the decreased $[\mathrm{Sr}]_{\mathrm{H}}$ level. Even with $[\mathrm{Ca}]_{\mathrm{P}}=7$, the upper $\mathrm{Ca}$ level is always at $[\mathrm{Ca}]_{\mathrm{H}}=50$ by the equilibrium with the homeostatic serum $[\mathrm{Ca}]_{\mathrm{I}}$ through 


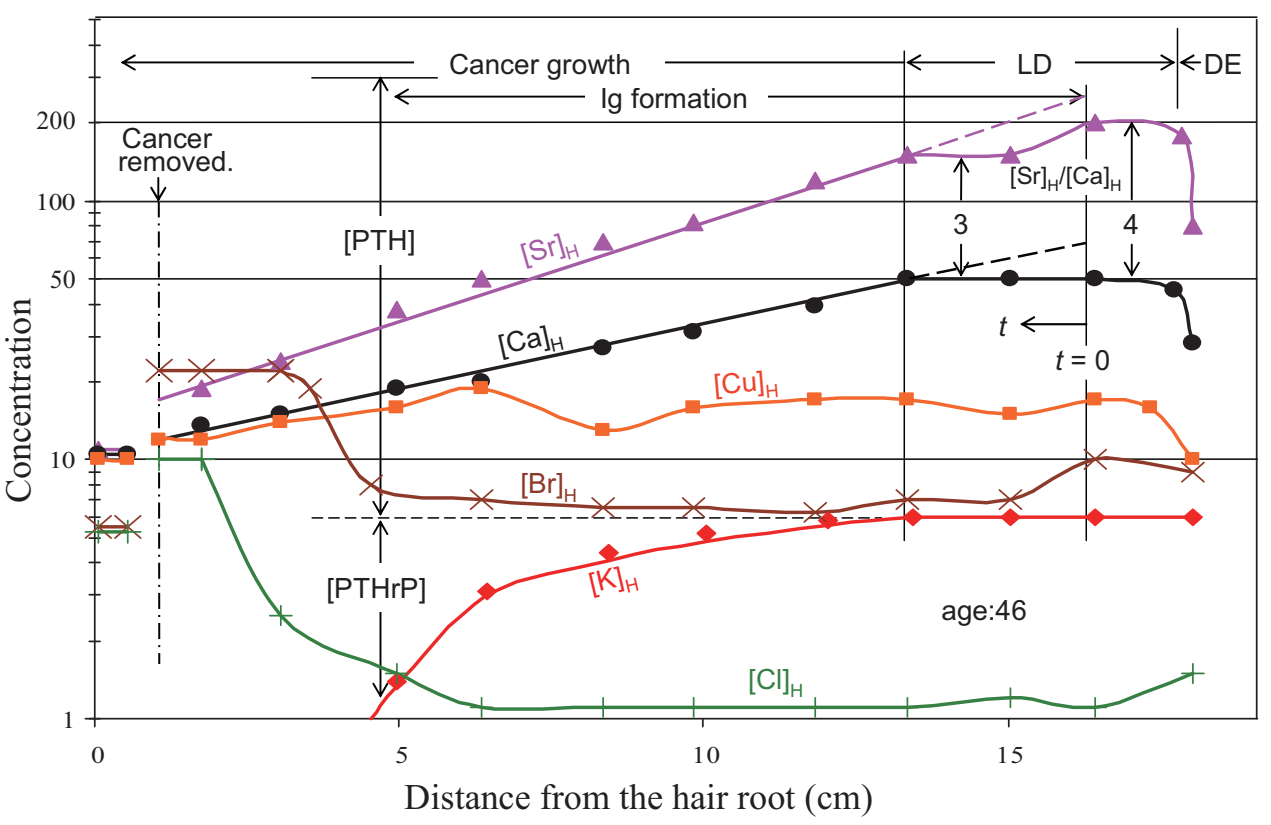

Fig. 7. Generation and growth of breast cancer with formation of immunoglobulin (Ig) from an LD type observed along a single hair strand of the patient. At the hair tip, $[\mathrm{Ca}]_{\mathrm{H}}$ and $[\mathrm{Sr}]_{\mathrm{H}}$ transit from their lower level to upper level as a DE type. In the duration of $[\mathrm{Ca}]_{\mathrm{H}}=50$ for about 4 months, $[\mathrm{Sr}]_{\mathrm{H}} /[\mathrm{Ca}]_{\mathrm{H}}$ decreases from 4 to 3 by Ig formation. From the Ca upper level, the $[\mathrm{Ca}]_{\mathrm{H}}$ decays by the straight line drawn so as to fit most of the $[\mathrm{Ca}]_{\mathrm{H}}$ measurement points marked with the circles. Similarly, the straight line for $[\mathrm{Sr}]_{\mathrm{H}}$ can be drawn. The relation of Eq. (22) is seen for both the lines. The curve for $[\mathrm{K}]_{\mathrm{H}}$ is obtained from the $[\mathrm{Ca}]_{\mathrm{H}}$ straight line by introducing a dwell time of PTHrP on the receptor 150 times longer than that of PTH and fits well the $[\mathrm{K}]_{\mathrm{H}}$ measurement points marked with the diamonds. Without the limit of the serum $\left[\mathrm{Ca}^{2+}\right]$ for the $\left[\mathrm{Ca}^{2+}\right]$ accumulated in cells by channel gating, the $[\mathrm{Ca}]_{\mathrm{H}}$ could have exceeded the upper $[\mathrm{Ca}]_{\mathrm{H}}=50$ level. Then, the decay line should be extrapolated toward the point $t=0$ of cancer generation at the initiation of the Ig formation, as shown by the dashed line. The cancer has cell divisions of 6 cycles in the process, and the cancer size at $t=0$ is estimated to be less than $1 \mathrm{~mm}$. The straight decay of $[\mathrm{Ca}]_{\mathrm{H}}$ means that the serum [PTHrP] at a time $t$ is the amount accumulated from $t=0$ [See Eq. (26)]. The low [Cl $]_{\mathrm{H}}$ values approaching noise level is due to the $\mathrm{Ca}$ inflows into the erythrocytes through the gating $\mathrm{Ca}$ channels which deteriorate the chloride shift. The $[\mathrm{Cl}]_{\mathrm{H}}$ level then increases toward the normal value simultaneously with the recovering of $[\mathrm{Cu}]_{\mathrm{H}}$ regulated by the liver function. The $[\mathrm{Cu}]_{\mathrm{H}}$ is shown with the normalization by Eq. $(2 \mathrm{~N})$. (Colours are visible in the online version of the article; http://dx.doi.org/10.3233/XST-140447)

the gating $\mathrm{Ca}^{2+}$ channels of the $\mathrm{HM}$ cells, and both the drops of $[\mathrm{Br}]_{\mathrm{H}}$ and $[\mathrm{Sr}]_{\mathrm{H}}$ are due to the dilution effect by an increase of serum protein concentration. In general, increase of the total serum protein could be expected from the formation of immune response proteins, such as immunoglobulin A. Therefore, the observed result can be attributed to the formation of immunoglobulin induced by the cancer generation, which lasts over the long process as seen from the term of $[\mathrm{Br}]_{\mathrm{H}}<10$.

\subsection{Formulation of the Cancer process}

The process in Fig. 7 can be formulated as a straight decay of $[\mathrm{Ca}]_{\mathrm{H}}\left(\right.$ and $\left.[\mathrm{Sr}]_{\mathrm{H}}\right)$. Now we introduce the dwell times $\tau_{\mathrm{O}}$ and $\tau_{\mathrm{C}}$ of PTH and PTHrP on their common receptors of cells, respectively. PTH and PTHrP have the amino-terminal region with high structure homology and are expected to have the same action on cell through the receptor. Every time when PTH or PTHrP binds to their receptor for Ca channel gating, a pulsed $\mathrm{Ca}^{2+}$ inflow into the cell occurs. So, frequent channel gating builds the intracellular $\left[\mathrm{Ca}^{2+}\right]$ up to the serum concentration. The process starts from the $\mathrm{Ca}$ upper level with 
channel gating by PTH and then PTHrP is added by the cancer. With both [PTH] and [PTHrP] in serum, the probabilities for a receptor to be occupied by PTH and PTHrP are given by $\tau_{\mathrm{O}}[\mathrm{PTH}] /\left(\tau_{\mathrm{O}}[\mathrm{PTH}]\right.$ $\left.+\tau_{\mathrm{C}}[\mathrm{PTHrP}]\right)$ and $\tau_{\mathrm{C}}[\mathrm{PTHrP}] /\left(\tau_{\mathrm{O}}[\mathrm{PTH}]+\tau_{\mathrm{C}}[\mathrm{PTHrP}]\right)$, respectively. The PTHrP occupation may be longer than the time required for building up the $\mathrm{Ca}$ accumulation for the upper level $[\mathrm{Ca}]_{\mathrm{H}}=50$ by the channel gating with the frequent PTH stimulation. The time ratio between channel closing and gating for a cell is equal to the number ratio between channel closing and gating cells, i.e.,

$$
\left(\tau_{\mathrm{C}}[\mathrm{PTHrP}]\right) /\left(\tau_{\mathrm{O}}[\mathrm{PTH}]\right)=x /(1-x)
$$

To find the ratio of $\tau_{\mathrm{C}} / \tau_{\mathrm{O}}$ in dwell time, the $[\mathrm{K}]_{\mathrm{H}}$ was measured along the hair shaft, showing a decay form different from those of $[\mathrm{Sr}]_{\mathrm{H}}$ and $[\mathrm{Ca}]_{\mathrm{H}}$, as seen in Fig. 7. The tip part of hair is believed to correspond to a cancer-free state, with the $[\mathrm{K}]_{\mathrm{H}}$ value as low as $[\mathrm{K}]_{\mathrm{H}}=6$ by the high $[\mathrm{PTH}]$ attributable to the $\mathrm{Ca}$ deficiency until the cancer generation. After that, the $[\mathrm{K}]_{\mathrm{H}}$ decreases rapidly to noise level.

PTH (PTHrP) inhibits the $\mathrm{H}^{+} / \mathrm{Na}^{+}$exchange in the renal proximal convoluted tubular cells to cause an increase of serum $\left[\mathrm{H}^{+}\right]$and a decrease of intracellular $[\mathrm{K}]$ by $\mathrm{K}^{+} / \mathrm{H}^{+}$exchange in cells. This deterioration in the renal $\mathrm{H}^{+}$excretion occurs by binding $\mathrm{PTH}$ or $\mathrm{PTHrP}$ to the $\mathrm{PTH} / \mathrm{PTHrP}$ common receptors on the renal tubular cells [12]. If we assume that one event on the receptor results in one exchanging $\mathrm{H}^{+} / \mathrm{K}^{+}$in cells, the decrease of $[\mathrm{K}]_{\mathrm{H}}$ is proportional to $[\mathrm{PTH}]$ (or [PTHrP]) in serum in a steady state (the $\mathrm{K}$ is excreted from the serum to maintain electric neutrality). As illustrated in Fig. 7, the level of $[\mathrm{K}]_{\mathrm{H}}=6$ is due to the reduction from the normal value $[\mathrm{K}]_{\mathrm{H}}=300$ by PTH secreted with the Ca deficiency, and the further decrease from $[\mathrm{K}]_{\mathrm{H}}=6$ is due to PTHrP secreted from the cancer. Then, by putting $[\mathrm{PTHrP}] /[\mathrm{PTH}]=\left(6-[\mathrm{K}]_{\mathrm{H}}\right) /(300-6)$, we obtain

$$
[\mathrm{K}]_{\mathrm{H}}=6-(300-6)\left(\tau_{\mathrm{O}} / \tau_{\mathrm{C}}\right) x /(1-x),
$$

using $x$ in the straight decay of $[\mathrm{Ca}]_{\mathrm{H}}$ in Fig. 7. The calculated curve $[\mathrm{K}]_{\mathrm{H}}$ with $\tau_{\mathrm{C}} / \tau_{\mathrm{O}}=150$ fits well with the point measurements. It is concluded that the large difference in dwell time between PTH and PTHrP can make the early detection of cancer possible.

Dwell time $\tau$ is the reciprocal of the reaction rate given by Arrehenius' equation:

$$
1 / \tau=A \exp (-E / k T),
$$

where $k$ is the Boltzmann constant and $T$ is the temperature. The binding energy $E$ with the receptors is nearly the same between PTH and PTHrP by their high structural homology, but the frequency term $A$ depends strongly on the length of molecule. PTH is a single chain polypeptide that comprises 84 amino acids. PTHrP occurs as fragments of great variety, although there are long molecules such as PTHrP1139. Therefore, the large difference in dwell time between PTH and PTHrP comes from the difference in this frequency term. In fact, PTH must have a short dwell time to respond quickly to any variation in $[\mathrm{Ca}]_{\mathrm{S}}$, and the difference with PTHrP is reasonable.

Using Eq. (23), we can rewrite Eq. (20) as

$$
[\mathrm{Ca}]_{\mathrm{H}}=[\mathrm{Ca}]_{\mathrm{P}}+\left\{(1 / 2)[\mathrm{Ca}]_{\mathrm{I}}^{2}-[\mathrm{Ca}]_{\mathrm{P}}\right\} \tau_{\mathrm{O}}[\mathrm{PTH}] /\left(\tau_{\mathrm{O}}[\mathrm{PTH}]+\tau_{\mathrm{C}}[\mathrm{PTHrP}]\right)
$$

For a straight decay in a logarithmic coordinate, we must put

$$
\tau_{\mathrm{O}}[\mathrm{PTH}] /\left(\tau_{\mathrm{O}}[\mathrm{PTH}]+\tau_{\mathrm{C}}[\mathrm{PTHrP}]\right)=\exp (-\gamma t),
$$

where $\gamma$ is the gradient of the decay and $t$ is a time from the cancer start of PTHrP secretion as illustrated in Fig. 7. We rewrite this as

$$
\left(\tau_{\mathrm{C}}[\mathrm{PTHrP}]\right) /\left(\tau_{\mathrm{O}}[\mathrm{PTH}]\right)=\exp (\gamma t)-1 .
$$


The right side, $\exp (\gamma t)-1$, is the summation of a geometric series, $1+2+2^{2}+2^{3}+\cdots+2^{n-1}=$ $2^{n}-1$ and indicates the cancer growth with the cell cycle time $t_{0}$ given by $\exp \left(\gamma t_{0}\right)=2$. Therefore, Eq. (26) gives the accumulative amount of PTHrP secreted from $t=0$ to $t$. Since the cell number after $n$ divisions of a cancer cell is $2^{n}$, serum [PTHrP] can be considered to be proportional to the number of the cancer cells at $t\left(2^{n}-1 \sim 2^{n}\right.$ for a large $\left.n\right)$.

The time for $t=0$ should be the point of the cancer generation. The intracellular $\left[\mathrm{Ca}^{2+}\right]$ increases by the accumulation of $\mathrm{Ca}$ inflow into the cells through the gating channels and is limited by the serum $[\mathrm{Ca}]_{\mathrm{I}}$. If the $[\mathrm{Ca}]_{\mathrm{I}}$ were higher, the $[\mathrm{Ca}]_{\mathrm{H}}$ could have exceeded the upper $[\mathrm{Ca}]_{\mathrm{H}}=50$ level. Then, the decay line in Fig. 7 should be extrapolated as shown by the dashed line with assuming the cancer generation at the initiation of the Ig formation. The cancer cell division cycles start at $t=0, t=t_{0}, t=2 t_{0}, t=$ $3 t_{0}, t=4 t_{0}, \cdots$. Using Eq. (26), the cycle number can be calculated to be 6 times near the root, where the number of the cancer cells is assumed to reach 30 million as a detectable size by the conventional diagnosis. Then, the initial cell number must be one 64th of the reached size, i.e., 500 thousand (less than $1-\mathrm{mm}$ in size) at $t=0$. If this is the critical size (nucleus) for cancer growth, the probability to reach it is so low as to result in a single generation of cancer.

In conclusion, hair $[\mathrm{Ca}]_{\mathrm{H}},[\mathrm{Sr}]_{\mathrm{H}}$ and $[\mathrm{K}]_{\mathrm{H}}$ observed for a patient of breast cancer depend on $[\mathrm{PTH}]$ and $[\mathrm{PTHrP}]$ in serum and can be explained by the hormones' dwell time ratio $\tau_{\mathrm{C}} / \tau_{\mathrm{O}}=150$ on the PTH receptors. This large ratio of $\tau_{\mathrm{C}} / \tau_{\mathrm{O}}$ may be responsible for both functional homology and antagonism between PTH and PTHrP studied by other investigators [8]. The resulting change in the elemental composition of hair makes early cancer detection possible. In the example of Fig. 7, cancer might be detected at $6-10 \mathrm{~cm}$ from the root.

\subsection{Block diagram between hair elements and PTH/PTHrP}

Finally, the relations between PTH/PTHrP and elemental concentrations in serum and hair are summarized in Fig. 8. Starting from the blood at the upper left corner of the figure, when serum $[\mathrm{Ca}]$ increases, the thyroid gland secretes calcitonin acting to deposit $\mathrm{Ca}$ and $\mathrm{P}$ on bone. In response to drops in serum [Ca] due to Ca deficiency, parathyroid hormone PTH is secreted and mobilizes $\mathrm{Ca}$ and $\mathrm{P}$ from the bone into the serum. The PTH is systemic and activates the gating of $\mathrm{Ca}$ ion channels of cells to cause a toxic inflow of $\mathrm{Ca}$ into the cells observed as hair $\mathrm{Ca}$ upper level $[\mathrm{Ca}]_{\mathrm{H}}=50$ (normal: $[\mathrm{Ca}]_{\mathrm{H}}=10$ ), which deteriorates the function of hepatocytes to excrete excess metals and erythrocytes for the chloride shift. Cancer is formed at the $[\mathrm{Ca}]_{\mathrm{H}}$ upper level with the $\mathrm{Ca}$ inflow into the cells. Cancer cells secrete parathyroid hormone related peptide PTHrP which occupies the PTH/PTHrP common receptors of cells with a much longer dwell time on the receptors than that of PTH. The longer dwell time of PTHrP decreases the channel gating frequency to increase ion channel closing responsible for the $[\mathrm{Ca}]_{\mathrm{H}}$ decay and $[\mathrm{Sr}]_{\mathrm{H}} /[\mathrm{Ca}]_{\mathrm{H}}<4$ (=4 for non-cancer). Therefore, the deterioration of cell functions as seen for the $[\mathrm{Cu}]_{\mathrm{H}}$ and $[\mathrm{Cl}]_{\mathrm{H}}$ is reduced with the increase of $[\mathrm{PTHrP}]$. Both PTH and PTHrP act on renal proximal tubular cells through their common receptors to inhibit $\mathrm{Na}^{+}$-dependent cotransport of anions (sulphate, phosphate, amino acids, etc.) and $\mathrm{Na}^{+} / \mathrm{H}^{+}$exchange [12]. These inhibitions are responsible for $[\mathrm{S}]_{\mathrm{H}}=$ 200 (maximum) and extremely low $[\mathrm{K}]_{\mathrm{H}}$.

Ca deficiency with bone resorption is classified as the DO type with $\mathrm{Ca}^{2+}$ and $\mathrm{HPO}_{4}^{2-}$ channel closing, having $[\mathrm{Ca}]_{\mathrm{H}}=[\mathrm{Sr}]_{\mathrm{H}} \gtrsim 10$ and $[\mathrm{P}]_{\mathrm{H}} \gtrsim 10\left(\right.$ deviated to Alkalosis $\left.[\mathrm{Cl}]_{\mathrm{H}}=[\mathrm{Br}]_{\mathrm{H}}<10\right)$ as inserted in Fig. 8. Hypercalcemia accompanying cancer has a very high $[\mathrm{Ca}]_{\mathrm{H}}>100[5]$ which is considered to be due to a DO type.

The cause of such bone resorption is inferred to be by serum [PTHrP] increased with cancer growth as follows: The renal Ca reabsorption by PTH action is inhibited by the PTHrP occupation with its long 


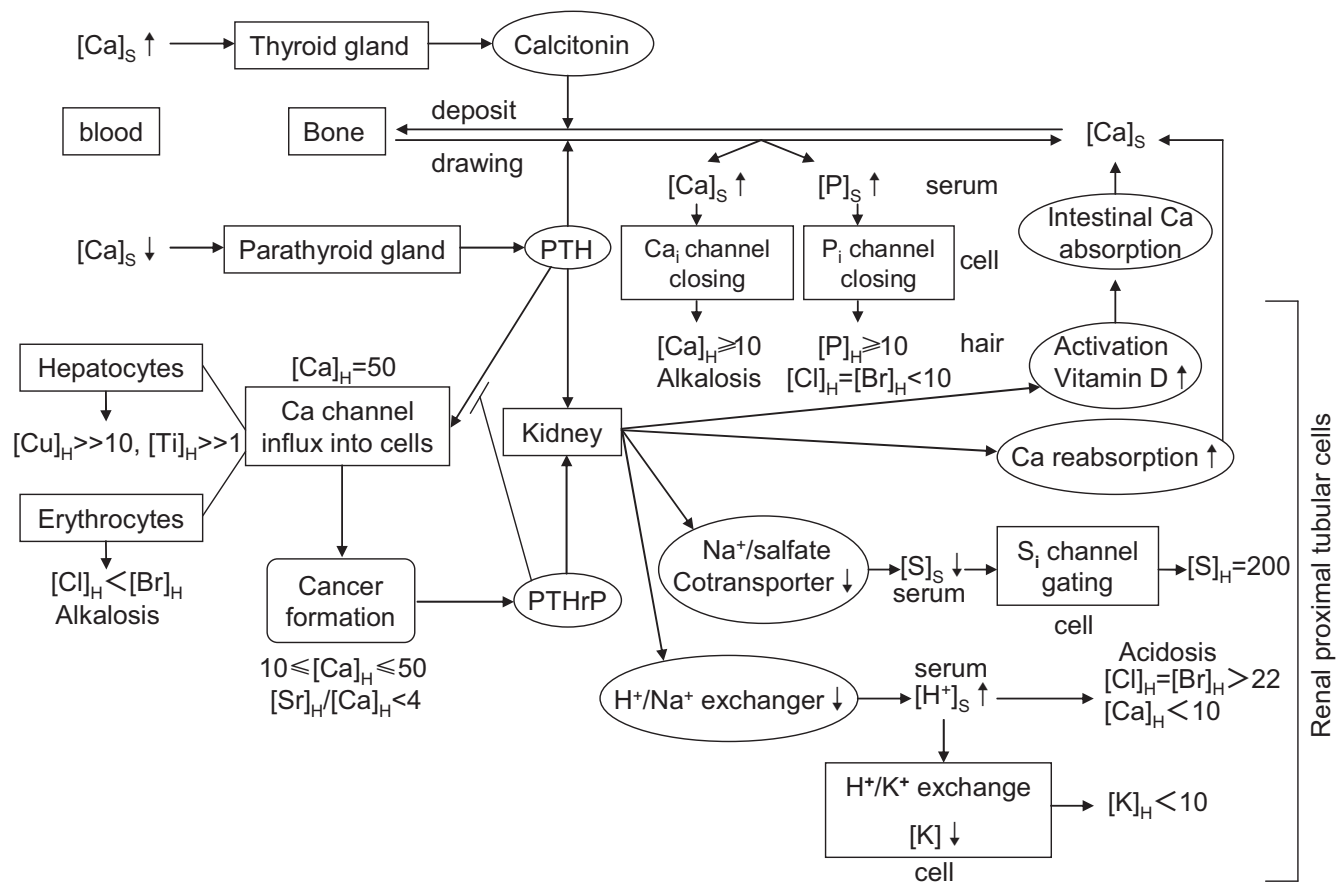

Fig. 8. Diagram showing the relations between PTH/PTHrP and elemental concentrations in serum and hair starting from Ca deficiency.

dwell time on the associated receptors. This makes the Ca deficiency serious and increases the serum $[\mathrm{PTH}]$ to promote the bone resorption; because of abundant amounts of the PTH/PTHrP receptors for bone resorption [7] the competition for the receptors between PTH and the less effective PTHrP does not take place. The existence of PTHrP in serum is considered to cause bone resorption with less renal Ca reabsorption.

\section{Conclusion}

The cancer process was found to leave evidence of itself as concentration abnormalities of various elements along hair strands. To read this memory, the relative concentrations defined by Eq. (2) without correction for hair thickness were measured by XFA. The content of an element in hair must be equal to the inflow of the element into the hair-making cells from serum. Elements having their ion channels in cell membrane were observed to have the upper and lower levels in hair concentration associated with ion-channel gating. Cancer is believed to be generated at the long-lasting upper level of hair [Ca] by PTH-operated channel gating, which decreases gradually toward the lower level with the cancer growth. This $[\mathrm{Ca}]$ decay process was formulated as a function of the concentration ratio $[\mathrm{PTHrP}] /[\mathrm{PTH}]$ in serum and dwell-time ratio $\tau_{\mathrm{C}} / \tau_{\mathrm{O}}(=150)$ on their common cellular receptors. The longer dwell time of PTHrP makes early cancer detection possible. Since the time ratio between channel closing and gating for a cell is equal to the number ratio between channel closing and gating cells, the longer dwell time of PTHrP is equivalent to the cancer criterion of $1<[\mathrm{Sr}]_{\mathrm{H}} /[\mathrm{Ca}]_{\mathrm{H}}<4$ due to Eqs (20) and (21) applicable for the range of $10<[\mathrm{Ca}]_{\mathrm{H}}<50$ without store-operated $\mathrm{Ca}$ channel gating. 
The long-lasting upper level of hair [Ca] was often observed without cancer, and was referred to as an "LD type" indicating a chronic Ca deficiency and possible cancer risk. The cancer generation from this type can be distinguished by whether the observed hair $[\mathrm{Ca}]_{\mathrm{H}}$ and $[\mathrm{Sr}]_{\mathrm{H}}$ have the ratio $[\mathrm{Sr}]_{\mathrm{H}} /[\mathrm{Ca}]_{\mathrm{H}}=4$ for $\mathrm{LD}$ type or $1<[\mathrm{Sr}]_{\mathrm{H}} /[\mathrm{Ca}]_{\mathrm{H}}<4$ for cancer.

The inflow of $\mathrm{Ca}$ (and $\mathrm{Sr}$ ) through gating $\mathrm{Ca}$ channels causes deterioration in cell functions, as seen from the two examples: (1) The Ca inflow into hepatocytes deteriorates the liver's function to excrete excess metals into bile, causing metal inflow and accumulation in cells. (2) The $\mathrm{Ca}$ ion inflow into erythrocytes results in alkalosis. Such abnormalities as well as the long-lasting $\mathrm{Ca}$ (and $\mathrm{Sr}$ ) inflow into cells totally may trigger the final stage of the mutation series [1] required for cell canceration. In fact, cancer generation at the upper $[\mathrm{Ca}]_{\mathrm{H}}$ level has been observed for other kinds of cancer encountered in these studies, such as lung, liver, prostate and the stomach. The observations in Figs 4-7 suggest that the long-lasting $\mathrm{Ca}(\mathrm{Sr})$ inflow into cells through gating channels is a necessary condition for cancer formation. It seems likely that calcium abnormalities are not only an effect but a cause of cancer, and that some cancer protection can be realized by maintaining a proper diet and avoiding significant calcium deficiency.

The hair analysis by XF provides a new diagnosis on cell ion channel gating. It serves as an indirect evaluation of PTHrP as a cancer marker, though the analysis of PTHrP itself has been problematic because of difficulties in quantitating it. Hair analysis is painless for the subjects and may bring an economic impact by early detection of cancer, in the evaluation of new cancer therapies, and in helping to define the role of diet in cancer prevention.

\section{Acknowledgements}

This work has been performed under the approval of the Photon Factory (Proposal No. 2005R15, 2006G408, 2009Y011, 2009Y022, 2010Y023) by collaboration with industries (Health Analysis Laboratory, Ltd.). The authors would like to express their sincere thanks to Professor A. Iida, Photon Factory, for his great help on the experiment at BL-4A. His sophisticated instrumentation made it possible to analyse the concentration variations along single hair strands. They are also indebted to Emeritus Professor T. Fujita (Kobe University), Emeritus Professor Y. Kudo (Tokyo University of Pharmacy and Life Sciences) and Professor K. Shinohara (Waseda University) for giving us much useful advice. The authors gratefully acknowledge great help throughout this work by Ms. S. Ooike in Centre for Advanced Science and Technology, Hyogo.

The authors would also like to acknowledge the review of the manuscript by Jeremy Salter (a retired pharmaceutical chemist).

Without the help of these persons and others whose help was less direct, this publication might be impossible, and the authors are deeply grateful for their efforts.

\section{References}

[1] B. Vogelstein and K.W. Kinzler, The multistep nature of cancer, Trends in Genetics 9 (1993), 38-141.

[2] A.W. Sorenson, M.L. Slattery and M.H. Ford, Calcium and colon cancer: A review, Nutr Cancer 11 (1988), $135-145$.

[3] E. Giovannucci, E.B. Rim, A. Wolk, A. Ascherio, M.J. Stampfer, G.A. Colditz and W.C. Wilett, Calcium and fructose intake in relation to risk of prostate cancer, Cancer Res 58 (1998), 442-447.

[4] T. Fujita and G.M.A. Palumieri, Calcium paradox disease: Calcium deficiency prompting secondary hyperparathyroidism and cellular calcium overload [review article], J Bone Miner Metab 18 (2000), 109-125. 
[5] J. Chikawa, K. Yamada, T. Akimoto, H. Sakurai, H. Yasui, H. Yamamoto, S. Okabe and M. Ebara, The universal concentrations and cancer signs of trace elements in hair observed by x-ray fluorescence analysis, $J$ X-Ray Science and Technology 15 (2007), 109-129.

[6] J. Chikawa, Y. Mouri, H. Shima, K. Yamada, H. Yamamoto and S. Yamamoto, Concentration homeostasis and standards of elements in hair and dried serum observed by X-ray fluorescence analysis using synchrotron radiation, $J X$-ray Science and Technology 22 (2014), 471-491.

[7] E.M. Brown and H. Jüppner, Parathyroid Hormone: Syntheses, Secretion, and Action, in Primer on the Metabolic Bone Diseases and Disorders of Mineral Metabolism, (Chapter 15, 6th edition), M.J. Favus, ed., Washington, D.C., American Society for Bone and Mineral Research, 2006, pp. 90-99.

[8] T. Fujita, Degenerative joint disease: An example of calcium paradox [review article], J Bone Miner Metab 16 (1998), 195-205.

[9] A.E. Broadus and R.A. Nissenson, Parathyroid hormone-related protein, in Primer on the Metabolic Bone Diseases and Disorders of Mineral Metabolism, (Chapter 16, 6th edition), M.J. Favus, ed., Washington, D.C., American Society for Bone and Mineral Research, 2006, pp. 99-106.

[10] T. Hirasawa, T, Nakamura, M. Morita, I. Ezawa, H. Miyakawa and Y. Kudo, Activation of dihydropyridine sensitive $\mathrm{Ca}^{2+}$ channels in rat hippocampal neurons in culture by parathyroid hormone, Neurosci Lett 256 (1998), 139-142.

[11] T. Hirasawa, T. Nakamura, A. Mizushima, M. Morita, I. Ezawa, H. Miyakawa and Y. Kudo, Adverse effects of an active fragment of parathyroid hormone on rat hippocampal organotypic cultures, Br J Pharmacol 129 (2000), 21-28.

[12] F.R. Bringhurst, Physiologic Actions of PTH and PTHrP II. Renal Actions, in The Parathyroids, Basic and Clinical Concepts, (Chapter 14, 2nd edition), J.P. Bilezikian, R. Marcus and M.A. Levine, eds, San Diego, Academic Press, 2001, pp. 227-243. 